\title{
Interorganizational Trust and Effectiveness Perception in a Collaborative Service Delivery Network
}

\author{
Krzysztof Opolski $@$, Piotr Modzelewski $@$ and Agata Kocia *(D) \\ Faculty of Economic Sciences, University of Warsaw, Warsaw, Poland Długa Street 44/50, 00-241 Warsaw, Poland; \\ kopolski@wne.uw.edu.pl (K.O.); pmodzelewski@wne.uw.edu.pl (P.M.) \\ * Correspondence: akocia@wne.uw.edu.pl
}

Received: 10 August 2019; Accepted: 18 September 2019; Published: 24 September 2019

\begin{abstract}
This study presents the determinants of trust in light of the scientific literature on trust and governance networks. The theoretical analysis focuses on differentiation of various types of trust and its determinants at both for-profit and nonprofit organizations. Moreover, the idea of a network is presented with the main attention given to the performance of collaborative service delivery networks. On the basis of theoretical study, a longitudinal analysis was performed at institutions providing services to the homeless people in Warsaw, Poland. During the periods of 2013 and 2017 to 2018, two cohorts of field questionnaire studies were conducted among employees of 18 social welfare centers (sample based on 18 Warsaw districts) and homeless shelters run by nonprofit organizations (samples of 19 and 22, respectively). These local government institutions and nonprofit organizations comprised the collaborative service delivery network under study. Mixed-method research was applied at welfare centers and nonprofit organizations (NGOs) where both frontline and management level employees were interviewed, and some data were statistically evaluated. The research was conducted using the same questionnaires at both points in time. The research showed that, from the perspective of social welfare centers, interorganizational trust in relation to other social welfare centers and to nonprofit organizations is positively correlated with perceived interorganizational effectiveness of other actors in the network (measured by the possibility of obtaining information, promptness, commitment, completeness and correctness of documents, and assessment of employees' knowledge). The same results were obtained from the perspective of NGOs. In addition, these correlations remained almost unchanged over time, although the research was repeated after many years using the same variables. Finally, there is no basis to state that trust is correlated with outcome perception when considering the most difficult and complex social services.
\end{abstract}

Keywords: interorganizational trust; collaboration; public service delivery network; performance measurement; perceived outcomes; homelessness

\section{Introduction}

In the scientific literature on governance networks, trust is treated as a key determinant of effectiveness in the area of public service delivery. According to Klijn et al. "there is very little research on the impact of trust in achieving results in governance networks" [1]. Moreover, literature overviews show that empirical works that consider the perspectives of various actors is also lacking. The literature on collaborative governance networks lacks research that enables scientists to verify the independency between trust and perceived effectiveness, and to understand the factors that trust depends on, as well as the relationships among trust and perceived interorganizational effectiveness. Following Berman, effectiveness is understood as "the level of outcomes, for example, [ ... ] the number of welfare clients who find employment after being counseled by caseworkers" [2] (pp. 5-6). In this study, we consider the effectiveness at two levels, perception of overall outcomes of the network and 
perception of interorganizational effectiveness among social welfare centers or nonprofit organization (NGO) employees. According to McNabb's [3] classification of question types at the cognitive stage, effectiveness is understood in our research as the exit from homelessness (factual and knowledge type questions), whereas, in our study, surveys at the affective stage asked employees of the network about their opinions (opinion and attitude type questions). The perceived outcomes for employees of social welfare centers are rather focused on facts and knowledge about the exit from homelessness statistics, but perceived outcomes for the NGO employees are broader and may also emphasize positive outcomes related to the process of the exit from homelessness and also positive results connected with the well-being of homeless people. Additionally, we used the term, interorganizational effectiveness, to refer to the possibility of obtaining information, informational flow, commitment, promptness, completeness and correctness of documents received, and assessment of employees' knowledge. The idea of interorganizational effectiveness is somewhat neglected in empirical research, although our study shows that it is particularly important in the context of interorganizational trust.

In order to assess trust, perceived outcomes, and perceived interorganizational effectiveness, in-depth interviews and surveys were conducted at different time frames to analyze changes in the relationships among trust and other variables over time. This study responses to identified research challenges, with both exploratory and explanatory elements, as it contributes the following three innovations to the literature on trust in collaborative public service delivery networks: (1) we conducted the analysis of trust determinants from different points of view (at social welfare centers and NGOs), (2) we proved that the determinants of trust are independent of the point of view among network actors and confirmed this conclusion in the research carried out at two different periods of time, (3) we did not confirm the impact of trust on perceived outcomes in a public service delivery network (providing social assistance services), but we identified strong premises that trust is dependent upon the perceived interorganizational effectiveness of the collaborating partners. With this in mind, the aim of our study is to verify the relationships between interorganizational trust and organizational effectiveness perception and between interorganizational trust and perceived outcomes of other entities in a collaborative network.

This study presents determinants of trust at institutions providing services to homeless people in Warsaw, Poland. Our longitudinal research consisted of two cohorts of field questionnaire studies, during 2013 and from 2017 to 2018, which were conducted among the following groups: (1) employees of 18 social welfare centers (sample based on 18 Warsaw districts) and (2) homeless shelters run by nonprofit organizations (samples of 19 and 22, respectively). An object of our study was a collaborative network providing services to the homeless in the City of Warsaw, and therefore the network comprised social welfare centers and nonprofit organizations working on behalf of the homeless.

The research was conducted using the same procedure and research tools at both points in time. We applied both a mixed method of qualitative research based on in-depth interviews and quantitative analysis based on data from the surveys, with the use of statistical methods in order to understand the determinants of trust and to measure statistical relationships. Mixed method can be defined as a study in which the researcher "collects and analyzes data, integrates the findings, and draws inferences using both qualitative and quantitative approaches or methods in a single study or a program of inquiry" [4] (p. 4). The research used different research questions (qualitative and quantitative approaches), different manners for developing research questions (participatory and preplanned), two types of data collection procedures (in-depth interviews and surveys), and two types of data (textual and numerical) [4]. The analysis involved preliminary study involving structured interviews with management staff at the entities of collaborative network during which questionnaires were prepared and tested. Next, with the use of the questionnaire the main research was conducted from two perspectives, social welfare centers and nonprofit organizations. The field results were analyzed using descriptive statistics, Kendall's Tau b correlation coefficient [5], and the Mann-Whitney U test for verifying differences in distributions of variables. Additionally, in-depth structured interviews were conducted in order to assess the causality between trust and other variables. 
According to B. Kozuch, public trust "can be system-based and institution-based trust or social trust" [6]. For this study, we consider both system-based and institution-based trust and, in particular, interorganizational trust in a collaborative network. Our research is set in the context of bounded rationality of individual actors in a public service delivery network with the emphasis on organizational trust, or more precisely interorganizational trust, in a collaborative public service delivery network.

Our study has been conducted at two different points in time and we have found that most of the correlations remained fixed over time. On the basis of an extensive literature study, we set and tested the following three hypotheses: (1) a positive correlation exists between interorganizational trust and the organizational effectiveness perception of other institutions in a collaborative network; (2) a positive correlation exists between interorganizational trust and the frequency of contact perceived between entities in a network; and (3) a positive correlation exists between interorganizational trust and the perceived outcomes of other institutions in a collaborative network.

Empirical research has shown that for the first and the second hypotheses there is no reason to reject them, while the third hypothesis has been rejected.

The first section of this paper begins with definitions of trust and especially interorganizational trust and its determinants. In addition, our literature review provides information about organizational effectiveness dimensions in collaborative governance networks such as flow of information, communication, knowledge, and job satisfaction. The second section describes the research sample, hypotheses, methods of analysis, questionnaire design, and research procedure. The next section describes the results from the perspectives of social welfare centers and nonprofit organizations. The fourth section provides the results of the research and conclusions.

\section{Background and Conceptual Framework}

\subsection{Trust Conditions and Determinants}

The issue of trust as an important factor of interorganizational relationships has been studied by various researchers. Trust can be defined as "an aspect of relationships", which means it varies "across relationships" [7] (p. 344). Trust can be perceived as an individual trait of a person. Such a broad approach to trust is applied by Deutsch [8], Sako [9], Mayer et al. [10], Bhattacharya et al. [11], and Paliszkiewicz [12]. Rousseau et al. define trust as a psychological state in which vulnerability is accepted in hope of a positive expectation [13]. A similar definition is applied by Mayer at al., but they add that trust involves no necessity to monitor or control the actions of another party. Rempel et al. [14] define trust as a state of believing in the other party causing an internal motivation for joint cooperation, while Paliszkiewicz presents trust as a belief that the trustor will not harm the trustee and will act in a mutually beneficial way. Therefore, various definitions of trust focus on the uncertainty of the outcome of the relationship that is an inherent risk of the cooperation, where trust serves as a "glue" where legal rules are absent [15]. On the other hand, being vulnerable to the other side also means that a person might be willing to do something outside of their scope of duties to protect the cooperative relationship. Schoorman et al. studied to what degree is a "trustor [ ... ] willing to voluntarily take risks at the hands of the trustee" [7] (p. 347). Therefore, trust can be a connector holding legally unstructured organizations together, while it can also lead to nonstandard decision making. Trust can be inherent to a relationship due to personal features or learned by interpersonal contact. The former means that trust is a personal characteristic of particular employees who pose a friendly and trustworthy attitude toward each other. The latter means that as a result of contact, trust is gained through positive experience. According to Strahorn et al. the learned aspect of trust is more conducive as it is built up as a result of a proven record of positive outcomes. In studying trust, Strahorn et al. believed that focus should be placed on determining whether trust is inherent in a relationship due to personal traits or due to learned partnership [16]. As these authors suggest, mistrust can develop if an initial trustworthy attitude towards cooperation is not supported by positive experiences. Regardless of the type of trust, this notion can be subdivided into a few elements. According to Mayer et al., trust is composed of 
perceived trust, benevolence, and integrity [10]. Perceived trust is a level of recognition of the other party's abilities and skills. In other words, the understanding that others possess abilities and skills to perform on their promises. Benevolence is a positive attitude in a relationship, an unwillingness to harm another human being, whereas integrity is an understanding of common values. For these researchers, elements of benevolence and integrity, as well as having common or different values between organizations, all have been important to the empirical analysis of perceived trust. Hartman lists determinants of trust but includes integrity, competencies, and intuition [17]. Nevertheless, Hartman's work seems in line with those of Mayer et al. as competencies can be seen as synonymous with perceived trust, whereas intuition with some level of benevolence $[10,17]$. In an interpersonal organizational context, an important point to be made here is that trust requires acknowledgment of each other's competences, that is, the knowledge (see [1]), abilities, and skills that can serve a common good. There must also be a belief that the other side not only can, but also is willing to engage in activity which will bring benefits to the other side. Additionally, resource dependency is an aspect of trust often discussed in the literature [18].

Identifying determinants of trust by other researchers was needed for explanatory research. Trust has been studied by various researchers both as an independent and dependent variable. Harrison et al. studied volunteering in organizations [19] and various correlations, for example, between stewardship and organization and the public. When studying interorganizational trust, their conclusions are useful. In their research, trust is a measure of the organization and public relationship and was measured as a belief that organizational decisions will not be harmful to volunteers working for the organization. The authors also considered other elements of the organization and public relationship, including commitment and satisfaction. In this case commitment was measured as a belief by volunteers that the organization was willing to uphold its long-term ties to its volunteers, while satisfaction as the happiness by volunteers was measured from cooperation with the organization. The results showed a high level of involvement correlated with trust, commitment, and satisfaction, which is line with other research studies $[20,21]$. Such relationships can also exist among organizations (i.e., employees of these organizations), which is an important consequence for interorganizational research.

Following McEvily et al. [22], trust can positively impact organizations in two respects. Trust can impact on the ways people communicate with each other, and thus on processes such as negotiation, conflict management and resolution, teamwork, and creativity [23]. In the context of governance networks, similar findings were presented by Edelenbos and Klijn, as trust affects the flow of information and willingness to share information [24]. Trust can also impact job satisfaction and job performance. Therefore, the absence or presence of trust can affect hard measures such as financials [25] and transaction costs [26]. While trust seems essential for organizations, it may also be difficult to measure. Dirks [27] analyzed organizational trust as a mix of trust and authority and their impact on performance and reported that trust can be one of a few embodying principles and norms of organizations. Importantly, trust impacts not only on intraorganizational relationships, but also interorganizational relationships. Following Kożuch et al. [28], "trust determines the strength of relationships, both inside and between organizations". According to Santana et al. [29] organizational trust may affect the desired outcomes, and thus trust maintenance is crucial, also in open networks.

Trust in organizations depends upon many variables. The literature identifies six variables which compose trust. One of the variables is organizational support $[30,31]$ which takes into consideration how the organization cares for its constituents. Another important variable for trust development is communication whose aim is to share information between the sender and the receiver of the message [32-34]. Managerial support can favor trust building as it fosters a positive attitude at the workplace [35].

The literature shows that psychological empowerment [36,37], values [38,39] and principles [40] also can have an impact on trust. Psychological empowerment shows that managers trust their workers and believe in them by delegating duties to them for which all are jointly accountable. Furthermore, values are strongly connected with the moral and ethical norms of the organization such as cooperation 
and fairness. Principles are focused on legal aspects of cooperation, and therefore the rules of the game which employees obey. Thus, they shape the possibility for trust to build and develop in a legally secure environment.

\subsection{Collaborative Networks Performance and Trust}

When hierarchical forms of command and control are no longer the most effective methods for policy development and implementation, there is a need to create network structures or such forms are made spontaneously [41-44]. As a result, a much wider set of actors appears, consisting of also nongovernmental organizations [45-47]. A challenge is to measure the functioning of network structures and relationships inherent in them. Network performance assessment criteria have been widely discussed in the literature [48-55]. When assessing outcomes of a network the focus is often placed either on network management (e.g., administrative effectiveness, satisfaction of employees with governance, and frequency of interactions between actors) or on final results such as a community-level performance (e.g., better effectiveness) and an organizational-level performance (e.g., improved stakeholder relationships) [56].

In the theoretical literature some types of network accountability were distinguished, for example, democratic accountability (connected with policy goals) and administrative accountability of networks (connected with organizational goals) $[57,58]$. In our study, we call the results at the community-level performance "outcomes" and the results connected with organizational goals (level of fulfillment) "interorganizational effectiveness".

The outcome can be perceived by various employees internal to the network as well as external stakeholders, including the public at large. However, our focus has been on internal stakeholders of various organizations engaged in a collaborative network.

In collaborative relationships, trust can be considered as calculative trust and relational trust [59]. Calculative trust is the rational component of trust [59,60], and relational trust is the emotional aspect of trust [60] with no calculation [61]. Both dimensions of trust are meaningful to the interpretation of results in public service delivery networks. Achieving a high level of trust may stem from obtaining outcomes desired by a collaborative network in the form of high effectiveness, positive network management outcomes, and agreeable mutual relationships between stakeholders. Nevertheless, Vaccaro et al. states that "trusting relationships develop when transformational leaders are present in organizations, they are an essential ingredient of collaborative networks by providing leadership, meaningfulness, and direction towards common goals leading to desired outcomes" [62] (p. 17). In our empirical research we looked for such leaders, who could provide us with complex information regarding the homeless system in Warsaw.

According to Williamson, regardless of the form of the organization, in management the aims are focused on outcomes [63]. However, many researchers have assessed the various attributes of public service delivery network effectiveness $[48,64,65]$. In one of the research studies, the dependent variable was "perceived outcome of collaboration", while independent variables included joint decision-making, collaboration, sharing resources, and trust building [66]. The variable of perceived outcome was applied by Klijn et al. [1] where it was treated as "an important factor in establishing desired interactions and outcomes in governance networks" [1] (p. 196). In our study, we applied such a method, as perceived effectiveness and the relationships among actors in collaborative network were used. To reiterate, effectiveness is considered as "level of outcomes" [2] (p. 5) and, in our study, we applied precisely, the exit from homelessness, in particular from the perspective of social welfare centers. Another interesting approach was used by Burchielli et al. [67], who applying the notion of an ethical network defined as "collaboration of interconnected stakeholders with direct and indirect links" to an organization that "through combined activities and mechanisms, effect ethical [ ... ] outcomes". In our study, this approach is used to assess outcome perception by NGOs.

The economic literature differentiates among two types of accountability, strong accountability and weak accountability $[68,69]$. When "wicked problems" are considered, strong accountability 
and statistical data may not only be relied upon, but it may also be necessary to consider criteria developed as a result of relationships based on trust in collaborative networks. Furthermore, Provan and Milward present the following criteria of effectiveness: on the societal level, public opinion perception of problem resolution; on the network level, the strength of relationships, coordination of services, and engagement of employees in the network; and, on the level of the organization an improvement of organizational operations, ensuring resource availability, access to services, and client outcomes [70]. An interesting set of variables was used by a study by Kapucu, Garayew, and Wang [71] in the area of maintaining network functionality. In the area of convergence of organizational goals, they applied frequency of contact and also measured whether organizations in a network possess different organizational priorities. In the area of interorganizational trust, they verified whether interorganizational relationships are characterized by mutual trust and whether organizations in the network cooperate with a feeling of benevolence towards others. According to Kozuch and Jablonski, trust determines proper relationships with other stakeholders of public or social organizations [6]. Moreover, organizational trust means having positive expectations about an organization [72].

The determination of the effectiveness of public service delivery networks requires an examination of their inherent bounded rationality (some of them in [73]), but in a quantitative manner. An important dilemma is that decisions are often made under conditions of imperfect information, emotions, or convictions of the decision maker [74-76]. In a recent study, which appeared in the world literature, a multi-actor perspective is the approach applied in studying rationality in governance networks [77]. In our research we have applied the methodology of asking the same questions to various actors mutually assessing themselves.

From this it stems that the outcome measurement in collaborative networks should pertain not only to organizational effectiveness but also to outcomes and trust. Measuring trust should be conducted by encompassing various types of actors engaged in the networks. This will allow the researcher to carry out a neutral assessment and detect relationships among variables in the research sample. The calculative trust pertains more to expectations regarding obtained results in a network, while the relational trust is a necessary aspect of network functioning and builds by ensuring high organizational effectiveness. From the perspective of various actors in collaborative network structures we expect that calculative trust or relational trust may differ in importance depending on the actors.

\section{Materials and Methods}

\subsection{Research Sample}

This research has focused on studying a collaborative network of assistance to homeless people in Warsaw. It is a network formed of social welfare centers and nongovernmental organizations (NGOs) whose operations are conducted at the local government level of the City of Warsaw in Poland. Activities binding and tightening collaboration in the network originate both on the local government side and the organizations' side. The NGOs that are part of the network are co-financed by Warsaw's local government. As part of the collaboration joint planning, exchange of information, common work on behalf of homeless, as well as exchange of resources (human, tangible, and organizational) takes place.

The longitudinal research was conducted at all social welfare centers (18 Social Welfare Centers in 18 City of Warsaw districts with at least 1 response per social welfare center), and NGOs providing services to the homeless in the City of Warsaw (19 units in 2013 and 22 units from 2017 to 2018). All of these comprised the collaborative service delivery network at two different points in time. The network approach is strengthened by the fact that respondents were asked to assess the functioning of the other institutions (actors) in the network and the network as a whole.

The research from 2017 to 2018 used the same variables as the study conducted in 2013. The research sample consisted of 44 employees of social welfare centers in 2013 and 33 employees in 2018 as well as 17 employees of NGOs in 2013 and 36 employees of NGOs from 2017 to 2018. 


\subsection{Research Hypotheses}

In this research, interorganizational trust was measured through a personal opinion of employees. Therefore, trust was a subjective measure. The employees' perception could have been influenced by the hard outcome measure of the public service delivery network which is the exit from homelessness, since it was assumed they knew the statistics of coming out of homelessness. It must be emphasized that a high level of outcome measure may be difficult to achieve due to the nature of many homeless people such as elderly, addicted to alcohol, and with weak family ties. Thus, rather than focus on the outcome, nonprofit organizations focus on improving the conditions of the homeless and provide them with temporary housing and minimal financial support.

In the context of an interorganizational trust study and based on the literature review, the following research hypotheses were formulated:

H0: A positive correlation exists between interorganizational trust and organizational effectiveness perception of other institutions in a collaborative network.

H0: A positive correlation exists between interorganizational trust and frequency of contact perceived between entities in a network.

H0: A positive correlation exists between interorganizational trust and perceived outcomes of other institutions in a collaborative network.

Correlations were used to describe relationships between any two or more variables. The general assumption for null hypothesis in quantitative studies is that variables are independent [3] (p. 213). The authors believe that these variables are particularly important in the collaborative network of assistance to the homeless due to the difficulty of "wicked problems" and the necessity of ensuring organizational potential to tackle them.

\subsection{Methods of Analysis and Questionnaire Design}

In order to understand the issue of trust in the system of assistance to the homeless, an empirical research with selected representatives engaged in the system was conducted. The empirical study was divided into two main phases. Phase 1 included in-depth interviews at (a) social welfare centers and (b) NGOs, with open-ended questions about trust and semi-structured interviews with questions about trust determinants and the causality between trust and other variables. Phase 2 focused on structured interviews using open-ended and closed-ended questions at (a) social welfare centers and (b) at NGOs.

At the stage of in-depth interviews, the selected individuals were chosen from among the leading nonprofit organizations and social welfare centers in terms of effectiveness and innovativeness and which operate in districts with the highest number of organizations aiding the homeless. Firstly, a general question about what does trust depend on was posed to (a) other social welfare centers and NGOs from the perspective of social welfare centers and (b) other NGOs and social welfare centers from the perspective of NGOs. Simultaneously, a question was asked about the relationship between trust and perceived effectiveness achieved by NGOs and social welfare centers. Then, semi-structured interviews were conducted during which questions regarding determinants of trust identified during scientific research were asked in order to better understand the relationship between perceived trust and categories of perceived effectiveness.

During the questionnaire interviews, first, a preliminary research was undertaken in order to refine the questions. Next, the main research study was completed, while the following components of interorganizational effectiveness were tested: flow of information, promptness, commitment, completeness and correctness of documents received, and assessment of other organizations' employee knowledge.

The method applied to analyze the results of the surveys was nonparametric correlation analysis (Kendall's Tau b coefficient correlation analysis). The reasoning behind this was a use of four research samples with two of them being too small to apply an econometric linear model, where a problem of collinearity would exist. Questionnaire design was based on a seven-point Likert-type scale ranging from strongly disagree (1) to strongly agree (7). The research model covered trust, perceived outcome, 
and perceived interorganizational effectiveness measured by multiple items. All the items were identified from the literature to improve content validity and adequacy.

\subsection{Data Collection}

Both the preliminary and the main study conducted in 2013 allowed us to test and apply appropriate variables for measuring perceived organizational effectiveness of other actors in the collaborative network, frequency of contact, and outcomes perceived by the respondents. In the 2017 to 2018 period, the study was repeated using exactly the same variables.

It is not fully clear whether the research samples in 2013 and from 2017 to 2018 were identical, as there were five years between the two research periods and many respondents in the 2017 to 2018 sample could not remember if they had taken part in the prior 2013 study. Only 4 employees of NGOs from 2017 to 2018 said that they had taken part in the study in 2013 (29 employees said they had not taken part in the study and 3 employees did not answer this question). It is likely that more employees had taken part in the study in 2013 but did not remember this fact. Although the research sample in 2018 was not the same as that from 2013, the studied relationships were fixed over time and seemed resistant to changes in the sample of respondents, and therefore it could be said that the relationships were universal in nature. Due to the fact that in the 2018 study, twice as many NGOs participated as compared to the 2013 study, the similarity of results should be treated as further support.

\section{Results}

\subsection{Trust from the Perspective of Social Welfare Centers}

\subsubsection{The Results of In-Depth Interviews in Social Welfare Centers}

The first step of the study was qualitative research with open-ended questions and semi-structured interviews. The following answers were obtained from the interviews from the perspective of social welfare centers. In response to a question about the factors of trust between social welfare centers and NGOs, a director of one of the social welfare centers said that a common aim, joint values and competencies are most important in this relationship. Relationships are essential in contacts with nonprofit organizations and that is why "we take part in all Social Dialogue Commission and Homeless Assistance Council meetings". At times, employees of other institutions have a different approach and do know the Social Assistance Law, then, personal contact can show a gap in knowledge, competencies, or differences in values. This can undermine trust toward these people since "it is not enough to know each other, but it is important what that means for the cooperation". In many cases, getting to know each other better can positively impact on trust, since "as a result of the meeting we learn that NGO employees mean the same thing, but have a different approach to achieving the goal. For example, in some cases, a shelter does not want to accept an ill person, not because this person is using nappies and would be troublesome to the shelter, but because the shelter does not have an employee working at night and the person in a nappy would have to spend from $4 \mathrm{pm}$ to 8 am without any care. Conditions of agreement with the local government, in the case of that nonprofit organization, do not include a night shift for a nurse, however, changing nappies is not part of the job responsibilities of a social worker. Therefore, much depends on understanding the perspective of employees of other institutions. This is confirmed by a description of difficulties in measuring outcomes in networks by Klijn et al. as "specific goals are not usually formulated" and actors may "have their own goals" [1].

In regards to trust between a social welfare center and other social welfare centers, a director answered that the quality of documents is the most important, "if documents are well prepared then that builds trust in employees of other social welfare centers, as we have more contact with those people through documents than in person". It is different in the case of emergency intervention when more direct and telephone contact occur. In such cases this is more similar to relationships with nonprofit organizations, that is, a community based on common aims, values, and competencies. Trust of a 
social welfare center towards other social welfare centers also depends on "if we know that person as it may be a person who previously worked in our social welfare center", as well as "many of our employees have informal contacts with other social welfare center employees which is important in trust building". Timeliness is also important, as "we do not like when a document arrives one day before the legal deadline". The ability to obtain information builds trust as a lot depends on "if we obtain information just to questions posed or there is information sharing". According to an interviewee "the results obtained by social welfare centers are a consequence of work organization and competencies of employees, and if these are in line with expected results, our trust in them increases. But high professional and personal competencies of these employees are necessary. The approach to achieving the aim is important in trust building". To a question whether social welfare center employees show trust in other institutions and whether this can influence the perception of results achieved by these institutions, an answer was given that "trust is an effect of 'something'. We can help other institutions with something, we can share our knowledge, but if we do not trust them, we do not know how they will use that information." Therefore, it can affect, to some extent, the effectiveness of these institutions, but the interviewee said that this is not a dominating relationship. According to the interviewee, in assessment of nonprofit organizations, from the perspective of social welfare centers, engagement increases trust in that organization, for example, "if a homeless person is with an organization for seven years and could exit the state of homelessness, this leaves doubts regarding the engagement of the employees of the shelter in supporting a homeless exit from homelessness." Social welfare centers undertake activities to build their trust in NGOs and built a partnership with NGOs to get to know each other better and accept each other. According to the director of social welfare center trust can depend on the personal character of the person with whom we cooperate. If it is someone who "is grumpy, this creates distance from that person, even if their work is well-perceived". Personal communicative competencies of that person are also important since "if that person cannot communicate well, we do not understand each other and trust is undermined".

We have chosen determinants based on the literature overview and conducted empirical research which can influence trust in social welfare centers.

\subsubsection{The Results of Interviews Using Questionnaires at Social Welfare Centers}

The results obtained during interviews are supported by data from surveys obtained in both periods examined, both in 2013 and in 2018.

The distributions of some important variables are presented in the Table 1. Most of the variables have a left skewed distribution, only the variable, overall effect of the system perceived, has a slightly right skewed distribution.

Importantly, the overall assessment of the system effects (perceived) is quite low and its average value is 3.75 on a seven-point scale. The assessment has increased slightly between the examined periods (2013 and 2018), but there are no grounds to state that distributions of variables have changed. No differences were found in the distributions of the remaining variables examined between the years analyzed using the Mann-Whitney $U$ test. In the whole sample of social welfare center employees, the percentage of females is $81.1 \%$, the percentage of people aged 25 years and below 30 years is $6.8 \%$, aged 30 years and below 40 years is $32.4 \%$, aged 40 years and below 50 years is $40.5 \%$, and 50 years and below 65 years is $20.3 \%$. In the research sample $16 \%$ of people have a B.A. education, while $68 \%$ have a M.A.

The research showed various correlations between trust and other variables that remain stable over time for two samples of respondents in a collaborative network.

In the case of social welfare centers (see Table 2), trust was correlated with the following: assessment of the possibility of obtaining information from other social welfare centers at the level of 0.478 in 2013 and 0.315 in 2018; assessment of information flow from other social welfare centers at the level of 0.517 in 2013 and 0.464 in 2018; assessment of promptness of other social welfare centers at the level of 0.622 in 2013 and 0.430 in 2018; assessment of commitment of other welfare centers at the level of 0.630 
and 0.599, respectively; assessment of completeness and correctness of documents from other social welfare centers at the level of 0.399 and 0.507 , respectively; and assessment of knowledge of employees of other welfare centers at the level of 0.522 and 0.611 , respectively. We expected a correlation between trust at social welfare centers and frequency of contact with other social welfare centers, however, this correlation proved to be insignificant.

Similar results on trust and its correlations with other variables were obtained based on responses provided by employees of social welfare centers in relation to employees of NGOs (see Table 3). For the variable, assessment of possibility to obtain information from the shelters, the correlation was at the level of 0.433 in 2013 and 0.364 in 2018 and for the variable, assessment of information flow from shelters was at the level of 0.556 in 2013 and 0.461 in 2018. Other variables also demonstrated a positive correlation, which included assessment of promptness of shelters at the level of 0.621 in 2013 and 0.458 in 2018; assessment of commitment of shelters at the level of 0.367 and 0.472 , respectively; assessment of completeness and correctness of documents from shelters at the level of 0.543 and 0.684 , respectively; and assessment of knowledge of employees of shelters at the level of 0.341 and 0.286 , respectively (the second correlation coefficient was significant at the level of 0.10 in the case of a two-side correlation. In the article a conservative approach to two-side correlation was applied whether than one-side correlation. Most of the correlations which in the article achieved a level of 0.1 were also statistically significant at the level of 0.05 for a one-side correlation.) In addition, in the case of the correlation between trust and the variable, frequency of contact with shelters, this proved to be insignificant.

Therefore, the analyzed correlations are fixed over time and independent of the institution studied. The correlations are objective and should also exist when assessing other types of public institutions in public service delivery networks. Nevertheless, it should be emphasized that in the case of the homeless service provision network in Warsaw, these relationships exist among actors with whom the frequency of contact is the highest in the network. These actors not only exchange information among each other, but also take part in joint planning and, to some extent, exchange of resources of their common use.

A summary of correlation analysis from the perspective of social welfare centers is presented in Figure 1. The direction of arrows was determined by the results of in-depth interviews with the management staff of the researched organizations (the mixed methods were used here in the presentation of results in Figure 1). There are reasons to believe that causality is true but confirmation of this requires further research based on different research samples. Since trust has an effect on studied organizational effectiveness, these factors can, therefore, to some extent be treated as determinants of trust.

Table 1. Perspective of social welfare center employees and descriptive statistics for chosen variables.

\begin{tabular}{|c|c|c|c|c|c|c|c|c|}
\hline \multicolumn{2}{|c|}{ Year/Statistics } & $\begin{array}{l}\text { Overall } \\
\text { Assessment } \\
\text { of Effects }\end{array}$ & $\begin{array}{c}\text { Overall } \\
\text { Assessment } \\
\text { of the } \\
\text { System }\end{array}$ & $\begin{array}{l}\text { Satisfaction } \\
\text { from Work }\end{array}$ & $\begin{array}{l}\text { Satisfaction from } \\
\text { Cooperation with } \\
\text { Other Social Welfare } \\
\text { Centers in Warsaw }\end{array}$ & $\begin{array}{l}\text { Satisfaction from } \\
\text { Cooperation with } \\
\text { NGOs }\end{array}$ & $\begin{array}{c}\text { Trust in Relation } \\
\text { to other Social } \\
\text { Welfare Centers } \\
\text { Employees in } \\
\text { Warsaw }\end{array}$ & $\begin{array}{l}\text { Trust in } \\
\text { Relation } \\
\text { to NGOs }\end{array}$ \\
\hline \multirow{4}{*}{2013} & Mean & 3.57 & 3.90 & 5.33 & 5.66 & 5.30 & 5.68 & 5.27 \\
\hline & $\mathrm{N}$ & 37 & 41 & 43 & 44 & 44 & 40 & 41 \\
\hline & Std. Deviation & 1.425 & 1.463 & 1.658 & 1.119 & 1.534 & 1.118 & 1.550 \\
\hline & Skewness & 0.039 & -0.327 & -1.371 & -0.524 & -0.890 & -0.812 & -0.771 \\
\hline \multirow{4}{*}{2018} & Mean & 3.97 & 3.94 & 5.09 & 5.42 & 5.13 & 5.41 & 5.35 \\
\hline & $\mathrm{N}$ & 31 & 33 & 33 & 33 & 32 & 32 & 31 \\
\hline & Std. Deviation & 1.354 & 1.499 & 1.756 & 1.001 & 1.540 & 1.160 & 1.253 \\
\hline & Skewness & 0.148 & -0.246 & -0.589 & -0.376 & -0.788 & -0.617 & -0.625 \\
\hline \multirow{4}{*}{ Total } & Mean & 3.75 & 3.92 & 5.22 & 5.56 & 5.22 & 5.56 & 5.31 \\
\hline & $\mathrm{N}$ & 68 & 74 & 76 & 77 & 76 & 72 & 72 \\
\hline & Std. Deviation & 1.397 & 1.469 & 1.694 & 1.070 & 1.528 & 1.137 & 1.421 \\
\hline & Skewness & 0.057 & -0.283 & -0.987 & -0.421 & -0.826 & -0.703 & -0.745 \\
\hline \multicolumn{2}{|c|}{ Mann-Whitney U } & 486.500 & 668.500 & 671.500 & 629.500 & 651.500 & 543.500 & 634.500 \\
\hline \multicolumn{2}{|c|}{ Wilcoxon W } & 1189.500 & 1529.500 & 1232.500 & 1190.500 & 1179.500 & 1071.500 & 1130.500 \\
\hline \multirow{2}{*}{\multicolumn{2}{|c|}{$\begin{array}{c}\mathrm{Z} \\
\text { Asymp. Sig. (2-tailed) }\end{array}$}} & -1.108 & -0.089 & -0.410 & -1.033 & -0.567 & -1.139 & -0.012 \\
\hline & & 0.268 & 0.929 & 0.682 & 0.302 & 0.571 & 0.255 & 0.991 \\
\hline
\end{tabular}

Source: own elaboration based on field research results. 
Table 2. Trust of social welfare centers to other social welfare centers.

\begin{tabular}{|c|c|c|c|c|c|c|c|c|c|c|c|c|c|c|}
\hline Area & Variable & Year & 1 & 2 & 3 & 4 & 5 & 6 & 7 & 8 & 9 & 10 & 11 & 12 \\
\hline \multirow{3}{*}{ Trust } & \multirow{3}{*}{ 1. Level of trust in relation with other Warsaw social welfare centers } & 2013 & 1.000 & & & & & & & & & & & \\
\hline & & 2018 & 1.000 & & & & & & & & & & & \\
\hline & & Overall & 1.000 & & & & & & & & & & & \\
\hline \multirow{17}{*}{$\begin{array}{l}\text { Organizational } \\
\text { effectiveness } \\
\text { (perceived) }\end{array}$} & \multirow{2}{*}{$\begin{array}{l}\text { 2. Assessment of possibility to obtain information from other } \\
\text { Warsaw social welfare centers }\end{array}$} & 2013 & 0.478 ** & 1.000 & & & & & & & & & & \\
\hline & & 2018 & $0.315^{*}$ & 1.000 & & & & & & & & & & \\
\hline & \multirow{3}{*}{$\begin{array}{l}\text { 3. Assessment of information flow from other Warsaw social } \\
\text { welfare centers }\end{array}$} & 2013 & $0.0417^{* *}$ & $\begin{array}{r}1.000 \\
0.472 * *\end{array}$ & 1.000 & & & & & & & & & \\
\hline & & 2018 & $0.464^{* *}$ & $0.291^{*}$ & 1.000 & & & & & & & & & \\
\hline & & Overall & $0.501^{* *}$ & $0.390^{* *}$ & 1.000 & & & & & & & & & \\
\hline & \multirow{3}{*}{ 4. Assessment of promptness of other Warsaw social welfare centers } & 2013 & 0.622 ** & $0.375^{* *}$ & $0.473^{* *}$ & 1.000 & & & & & & & & \\
\hline & & 2018 & $0.430^{* *}$ & 0.108 & $0.653^{* *}$ & 1.000 & & & & & & & & \\
\hline & & Overall & $0.531^{* *}$ & $0.249^{* *}$ & $0.552^{* *}$ & 1.000 & & & & & & & & \\
\hline & \multirow{3}{*}{$\begin{array}{l}\text { 5. Assessment of commitment of other Warsaw welfare service } \\
\text { centers }\end{array}$} & 2013 & $0.630^{* *}$ & $0.488^{* *}$ & $0.490^{* *}$ & $0.538^{* *}$ & 1.000 & & & & & & & \\
\hline & & 2018 & 0.599 ** & 0.097 & $0.438^{* *}$ & $0.265\left(^{*}\right)$ & 1.000 & & & & & & & \\
\hline & & Overall & $0.615^{\text {** }}$ & $0.345^{* *}$ & $0.472^{* *}$ & $0.433^{* *}$ & 1.000 & & & & & & & \\
\hline & \multirow{3}{*}{$\begin{array}{l}\text { 6. Assessment of completeness and correctness of documents from } \\
\text { other Warsaw social welfare centers }\end{array}$} & 2013 & $0.399^{* *}$ & $\left.0.237^{*}\right)$ & $0.322 *$ & $0.511^{* *}$ & $0.351^{* *}$ & 1.000 & & & & & & \\
\hline & & 2018 & $0.507^{\text {** }}$ & 0.042 & $0.361^{* *}$ & $0.332 *$ & $0.460^{* *}$ & 1.000 & & & & & & \\
\hline & & Overall & 0.459 ** & 0.146 & 0.351 ** & $0.434^{* *}$ & $0.381^{* *}$ & 1.000 & & & & & & \\
\hline & \multirow{3}{*}{$\begin{array}{l}\text { 7. Assessment of knowledge of employees of other Warsaw welfare } \\
\text { service centers }\end{array}$} & 2013 & $0.522^{\text {** }}$ & 0.218 & $0.489^{* *}$ & $0.492^{* *}$ & $0.492^{* *}$ & $0.573^{* *}$ & 1.000 & & & & & \\
\hline & & 2018 & $0.611^{* *}$ & 0.051 & $0.326^{*}$ & $\left.0.2611^{*}\right)$ & $0.675^{* *}$ & $0.614^{* *}$ & 1.000 & & & & & \\
\hline & & Overall & $0.574^{* *}$ & 0.149 & $0.417^{* * *}$ & $0.376^{* *}$ & $0.567^{* *}$ & $0.597 *$ & 1.000 & & & & & \\
\hline \multirow{3}{*}{ Contact } & \multirow{3}{*}{ 8. Frequency of contact with other Warsaw social welfare centers } & 2013 & -0.018 & -0.083 & -0.035 & -0.134 & 0.051 & 0.056 & -0.126 & 1.000 & & & & \\
\hline & & 2018 & 0.067 & 0.003 & 0.013 & -0.050 & 0.041 & 0.121 & 0.021 & 1.000 & & & & \\
\hline & & Overall & -0.006 & -0.089 & -0.007 & -0.093 & 0.040 & 0.081 & -0.058 & 1.000 & & & & \\
\hline \multirow{12}{*}{$\begin{array}{l}\text { Outcomes } \\
\text { perceived }\end{array}$} & \multirow{3}{*}{$\begin{array}{l}\text { 9. Satisfaction from cooperation with other Warsaw social welfare } \\
\text { centers }\end{array}$} & 2013 & 0.490 ** & $0.637^{* *}$ & $0.476^{* *}$ & $0.522 * *$ & 0.580 ** & $0.416 * *$ & $0.551 * *$ & 0.007 & 1.000 & & & \\
\hline & & 2018 & 0.397 ** & $0.362^{*}$ & $0.423^{* *}$ & $0.329^{*}$ & $0.426^{*}$ & $0.425 * *$ & $0.522^{* *}$ & 0.162 & 1.000 & & & \\
\hline & & Overall & 0.446 ** & $0.522^{* *}$ & $0.454^{* *}$ & $0.433^{* *}$ & $0.521^{* *}$ & $0.418^{* *}$ & $0.539^{* *}$ & 0.058 & 1.000 & & & \\
\hline & \multirow{3}{*}{ 10. Satisfaction from work in the social welfare center } & 2013 & $0.285^{*}$ & $0.325 *$ & $0.240\left(^{*}\right)$ & $0.217\left(^{*}\right)$ & $0.410^{* *}$ & 0.169 & $0.255\left(^{*}\right)$ & 0.074 & $0.414^{* *}$ & 1.000 & & \\
\hline & & 2018 & 0.175 & 0.097 & -0.136 & $-0.248\left(^{*}\right)$ & 0.162 & 0.144 & 0.227 & 0.174 & $0.268\left(^{*}\right)$ & 1.000 & & \\
\hline & & Overall & $0.238^{*}$ & $0.199 *$ & 0.081 & 0.008 & $0.290^{* *}$ & 0.161 & $0.264 *$ & 0.110 & 0.342 ** & 1.000 & & \\
\hline & \multirow{3}{*}{ 11. Overall assessment of the homeless assistance system in Warsaw } & 2013 & 0.209 & $0.243\left(^{*}\right)$ & $0.304^{*}$ & 0.203 & 0.198 & 0.168 & 0.117 & -0.060 & $0.310^{*}$ & $0.400^{* *}$ & 1.000 & \\
\hline & & 2018 & 0.028 & 0.209 & 0.102 & -0.058 & 0.158 & -0.066 & 0.145 & -0.120 & $0.277\left(^{*}\right)$ & $0.391^{\text {** }}$ & 1.000 & \\
\hline & & Overall & 0.124 & $0.214^{*}$ & $0.225^{*}$ & 0.067 & $\left.0.177^{*}\right)$ & 0.031 & 0.143 & -0.085 & $0.285^{* *}$ & $0.385^{* *}$ & 1.000 & \\
\hline & \multirow{3}{*}{$\begin{array}{l}\text { 12. Overall assessment of effects of the homeless assistance system } \\
\text { in Warsaw (in terms of getting out of homelessness) }\end{array}$} & 2013 & 0.124 & 0.083 & $0.274^{*}$ & 0.190 & 0.097 & 0.152 & -0.016 & -0.038 & 0.105 & 0.218 & $0.530^{\text {** }}$ & 1.000 \\
\hline & & 2018 & 0.079 & 0.206 & -0.178 & -0.233 & 0.120 & 0.075 & 0.181 & 0.046 & $\left.0.287^{*}\right)$ & $0.433^{* *}$ & 0.552 ** & 1.000 \\
\hline & & Overall & 0.112 & 0.128 & 0.073 & -0.007 & 0.100 & 0.114 & 0.089 & 0.016 & $0.172\left(^{*}\right)$ & $0.297^{* *}$ & 0.536 ** & 1.000 \\
\hline
\end{tabular}

Correlation (two-sided) significant at a level: ${ }^{* *} 0.01,{ }^{*} 0.05,{ }^{(*)} 0.10$. Source: own elaboration based on field research results 
Table 3. Trust of social welfare centers to the NGOs (shelters).

\begin{tabular}{|c|c|c|c|c|c|c|c|c|c|c|c|c|c|c|}
\hline Area & Variable & Year & $\mathbf{1}$ & 2 & 3 & 4 & 5 & 6 & 7 & 8 & 9 & 10 & 11 & 12 \\
\hline \multirow{3}{*}{ Trust } & \multirow{3}{*}{ 1. Level of trust in relationships with shelters } & 2013 & 1.000 & & & & & & & & & & & \\
\hline & & 2018 & 1.000 & & & & & & & & & & & \\
\hline & & Overall & 1.000 & & & & & & & & & & & \\
\hline \multirow{16}{*}{$\begin{array}{l}\text { Organizational } \\
\text { effectiveness (perceived) }\end{array}$} & \multirow{2}{*}{$\begin{array}{l}\text { 2. Assessment of possibility to obtain information from } \\
\text { shelters }\end{array}$} & \begin{tabular}{|l|}
2013 \\
2018
\end{tabular} & $\begin{array}{r}0.433^{* *} \\
0.364^{*}\end{array}$ & 1.000 & & & & & & & & & & \\
\hline & & Overall & $0.405^{* *}$ & 1.000 & & & & & & & & & & \\
\hline & \multirow{3}{*}{ 3. Assessment of information flow from shelters } & 2013 & $0.556^{* *}$ & $0.492^{* *}$ & 1.000 & & & & & & & & & \\
\hline & & 2018 & $0.461^{* *}$ & $0.640^{* *}$ & 1.000 & & & & & & & & & \\
\hline & & Overall & $0.506^{* *}$ & $0.552^{* *}$ & 1.000 & & & & & & & & & \\
\hline & \multirow{3}{*}{ 4. Assessment of promptness of shelters } & 2013 & $0.621^{* *}$ & $0.465^{* *}$ & $0.626^{* *}$ & 1.000 & & & & & & & & \\
\hline & & 2018 & $0.458^{* *}$ & $0.527^{* *}$ & $0.615^{* *}$ & 1.000 & & & & & & & & \\
\hline & & Overall & $0.558^{* *}$ & $0.487^{* *}$ & $0.625^{* *}$ & 1.000 & & & & & & & & \\
\hline & \multirow{2}{*}{ 5. Assessment of commitment of shelters } & 2013 & $0.367^{* *}$ & $0.515^{* *}$ & $0.434^{* *}$ & $0.454^{* *}$ & 1.000 & & & & & & & \\
\hline & & Overall & $0.418^{* *}$ & $0.528^{* *}$ & $0.445^{* *}$ & $0.593^{* *}$ & 1.000 & & & & & & & \\
\hline & \multirow{3}{*}{$\begin{array}{l}\text { 6. Assessment of completeness and correctness of } \\
\text { documents from shelters }\end{array}$} & 2013 & $0.543^{* *}$ & 0.194 & $0.365^{* *}$ & 0.535 ** & $0.313^{* *}$ & 1.000 & & & & & & \\
\hline & & 2018 & $0.684^{* *}$ & $0.309^{*}$ & $0.348^{*}$ & $0.550^{* *}$ & $0.602^{* *}$ & 1.000 & & & & & & \\
\hline & & Overall & $0.596^{* *}$ & $0.241^{*}$ & $0.351^{* *}$ & 0.542 ** & $0.441^{* *}$ & 1.000 & & & & & & \\
\hline & \multirow{3}{*}{ 7. Assessment of knowledge of employees of shelters } & 2013 & $0.341^{* *}$ & 0.113 & $0.477^{* *}$ & $0.481^{* *}$ & $0.389^{* *}$ & $0.482^{* *}$ & 1.000 & & & & & \\
\hline & & 2018 & $0.286\left(^{*}\right)$ & $0.535^{* *}$ & $0.492 * *$ & $0.437^{* *}$ & $0.636^{* *}$ & $0.520^{* *}$ & 1.000 & & & & & \\
\hline & & Overall & $0.318^{* *}$ & $0.303^{* *}$ & $0.481^{* *}$ & $0.486^{* *}$ & $0.532^{* *}$ & $0.509^{* *}$ & 1.000 & & & & & \\
\hline \multirow{3}{*}{ Contact } & \multirow{3}{*}{ 8. Frequency of contact with shelters } & 2013 & 0.180 & -0.004 & 0.195 & 0.035 & 0.210 & -0.106 & -0.024 & 1.000 & & & & \\
\hline & & 2018 & 0.241 & $0.461^{* *}$ & $0.297 *$ & 0.186 & 0.251 & 0.212 & $0.299\left(^{*}\right)$ & 1.000 & & & & \\
\hline & & Overall & $0.206^{*}$ & $\left.0.1844^{*}\right)$ & $0.252^{* *}$ & 0.085 & 0.189 & 0.018 & 0.089 & 1.000 & & & & \\
\hline \multirow{9}{*}{ Outcomes perceived } & \multirow[b]{2}{*}{ 9. Satisfaction from cooperation with shelters } & 2013 & $0.672^{* *}$ & $0.478^{* *}$ & $0.593^{* *}$ & $0.563^{* *}$ & $0.606 *$ & $0.489 * *$ & $0.346^{* *}$ & 0.159 & 1.000 & & & \\
\hline & & 2018 & $0.482^{* *}$ & $0.634^{* *}$ & $0.585^{* *}$ & $0.683^{* *}$ & $0.763^{* *}$ & $0.529^{* *}$ & 0.691 ** & $0.299^{*}$ & 1.000 & & & \\
\hline & \multirow[t]{2}{*}{ 10. Satisfaction from work in the social welfare center } & 2018 & $0.247\left(^{*}\right)$ & 0.101 & 0.099 & 0.126 & $0.336^{*}$ & $0.324^{*}$ & $0.258(*)$ & 0.189 & 0.150 & 1.000 & & \\
\hline & & Overall & 0.082 & -0.067 & 0.040 & 0.044 & $0.209^{*}$ & 0.109 & $0.187(*)$ & 0.101 & 0.074 & 1.000 & & \\
\hline & \multirow{3}{*}{$\begin{array}{l}\text { 11. Overall assessment of the homeless assistance } \\
\text { system in Warsaw }\end{array}$} & 2013 & $\left.0.234 *^{*}\right)$ & 0.061 & $0.315^{*}$ & 0.182 & 0.066 & 0.177 & 0.197 & -0.159 & 0.200 & $0.400^{* *}$ & 1.000 & \\
\hline & & 2018 & 0.185 & 0.158 & 0.124 & 0.105 & $0.273\left(^{*}\right)$ & 0.247 & 0.217 & 0.052 & 0.197 & $0.391^{\text {** }}$ & 1.000 & \\
\hline & & Overall & $0.211^{*}$ & 0.112 & $0.229^{*}$ & 0.142 & $0.161\left(^{*}\right)$ & $0.198^{*}$ & $0.226^{*}$ & -0.071 & $0.207^{*}$ & $0.385^{* *}$ & 1.000 & \\
\hline & \multirow{2}{*}{$\begin{array}{l}\text { 12. Overall assessment of effects of the homeless } \\
\text { assistance system in Warsaw (in terms of getting out of } \\
\text { homelessness) }\end{array}$} & 2013 & 0.140 & 0.088 & 0.107 & 0.180 & 0.174 & $0.269^{*}$ & 0.178 & -0.180 & 0.124 & 0.218 & $0.530^{* *}$ & 1.000 \\
\hline & & \begin{tabular}{|l|}
2018 \\
Oyerall \\
\end{tabular} & $\frac{0.372^{*}}{0.226^{*}}$ & $\begin{array}{l}0.137 \\
0.110\end{array}$ & $\begin{array}{l}0.093 \\
0.097\end{array}$ & 0.203 & \begin{tabular}{|l|}
$0.358^{*}$ \\
$0.235^{2}$
\end{tabular} & $0.455^{* *}$ & 0.210 & $\begin{array}{l}-0.016 \\
-0.090\end{array}$ & $\begin{array}{l}0.274\left(^{*}\right) \\
0.0187\left(^{*}\right.\end{array}$ & $0.433^{* *}$ & $0.552^{* * *}$ & $\begin{array}{l}1.000 \\
1.000\end{array}$ \\
\hline
\end{tabular}

Correlation (two-sided) significant at a level: $\left.{ }^{* *} 0.01,{ }^{*} 0.05,{ }^{*}\right) 0.10$. Source: own elaboration based on field research results. 


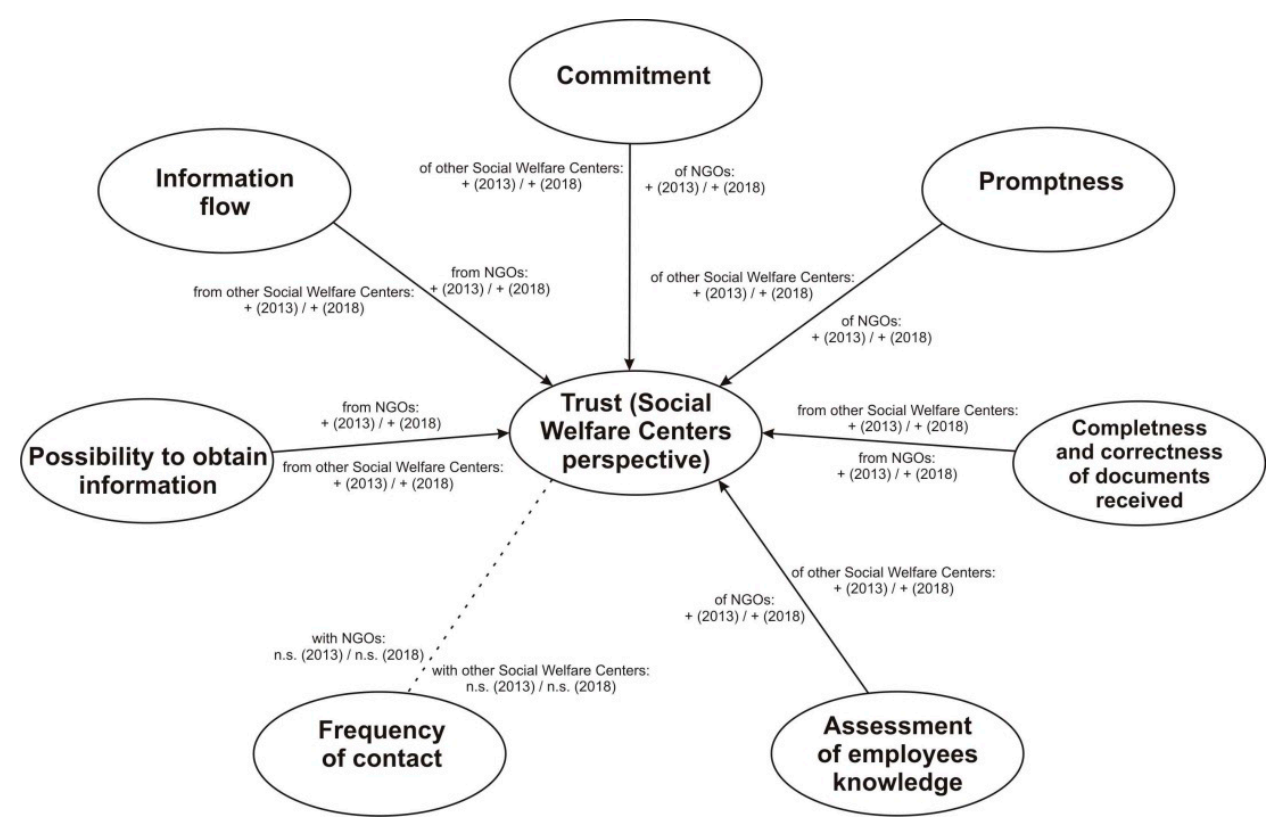

Figure 1. Correlations among interorganizational trust and perceived organizational effectiveness and the frequency of contact (perspective of social welfare centers), "n.s." = statistically insignificant, "+"=positive correlation, "-“ negative correlation. Source: own elaboration.

It clearly shows that all chosen variables assessing organizational effectiveness proved to be statistically significant and present only positive correlations. From the analysis, it stems that, for example, the better the information flow, the higher the trust in the institution from which the information is obtained. The more we perceive the engagement of a particular actors, or the more timely and complete the documents are, than the more trust we have in them. A similar result is obtained in the assessment of knowledge of employees of other organizations, that is to say, the greater the knowledge of these people, the greater the trust in them. However, in the case of this research sample there was no correlation between frequency of contact and trust.

Moreover, analysis in Figure 2 shows correlations among trust from the perspective of social welfare centers and variables pertaining to outcomes of the network (overall assessment of the system and overall assessment of effects) and outcomes of network management (satisfaction from cooperation and satisfaction from work). Only in the case, satisfaction from cooperation, it can be said that it is correlated with trust. For others, the correlations are inconclusive and the study should be repeated in this regard on other research samples pertaining to public services. 


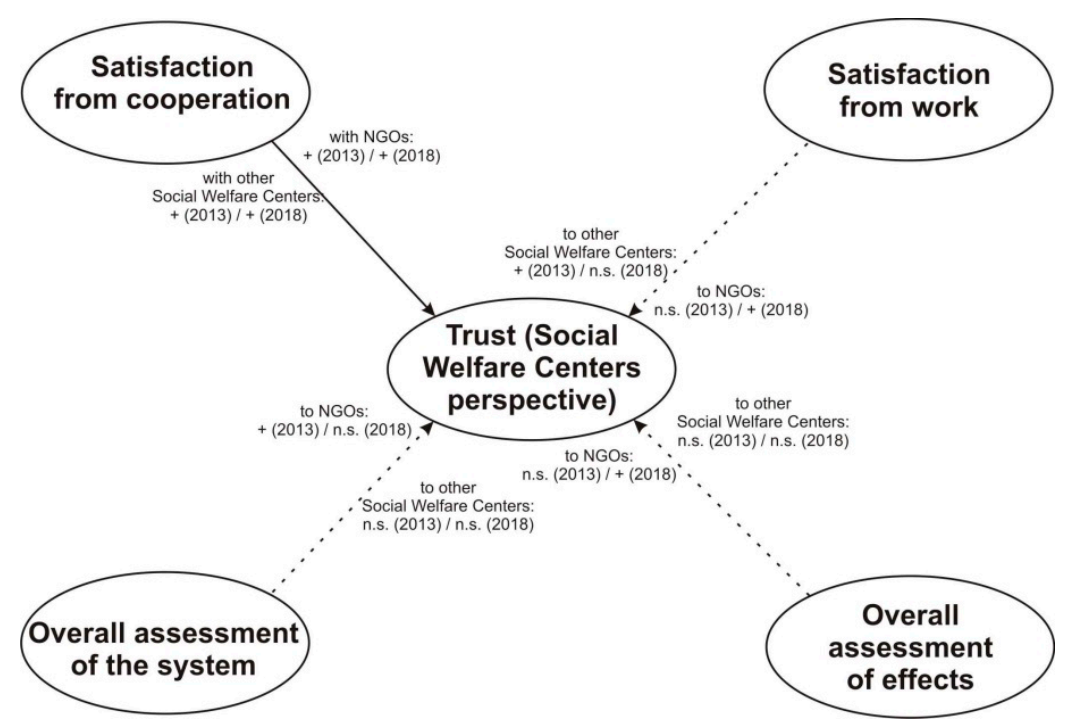

Figure 2. Correlations among trust from the perspective of social welfare centers and variables pertaining to the network outcomes and outcomes of the network management. Source: own elaboration.

\subsection{Trust from the NGOs Perspective}

\subsubsection{The Results of In-Depth Interviews in NGOs}

In the case of our study from the perspective of NGOs, first, the research procedure assumed in-depth interviews. The following answers from the NGOs perspective were obtained. From the perspective of NGOs, effectiveness is perceived differently than by other institutions, and also by social welfare centers. For nonprofit organizations leaving homelessness and having a home may not indicate higher effectiveness, for example, if the homeless became depressed due to loneliness and died from alcohol abuse. One NGO manager stated that "social welfare center employees must trust the NGO employees because every homeless person is different and sometimes for that person is not the best what the clerk might think. Many people after leaving a shelter dies lonely, informing frequently by phone that they do not want to be a home alone. There are critical situations, when employees of other institutions or city police officers are not able to grasp the situation of a person living on a street, and so they should trust NGOs since without this, providing effective assistance, is not possible. As part of the daily work conducted with people living in shelters, the NGO employees see the people a few hours per day for a year and so their knowledge about the life of the homeless is much greater than that of the employee of social welfare center who sees the homeless person mostly during a registration interview and for a short time in the later stages of care. In this situation, trust in the NGO by the social welfare center is even more necessary". It is interesting that trust is also needed between NGO and the homeless person, because without it the homeless will not agree to the assistance being provided to them. This is rather difficult as homeless generally do not trust institutions.

According to the NGO manager, the definition of effective assistance may be drastically different from that of social welfare center employees. From the perspective of nonprofit organizations, effectiveness is a "change which occurred within the homeless". An initial success can be that homeless "will go to the doctor and wash up", as success requires "a long-term relationship and empathy from NGO employees and achieving successive small steps by the homeless." Such managers can be treated as transformational leaders, who due to their high ethical standards and extensive knowledge, can built relational trust with other network stakeholders and obtain outcomes based on common values. On the other hand, a social welfare center clerk perceives effectiveness as a number of persons leaving homelessness, although they may not be able to lead an independent live.

Moreover, according to the NGO manager, trust is necessary when preparing financial plans, as social welfare centers may be afraid of cost increases and should trust that cost calculations presented 
by NGOs are adequate to their needs. An issue of trust can also exist from NGOs towards the city hall. Distrust can arise, for example, as a result of not maintaining agreements which have been set during meetings even when documentation from meetings is kept. Undermining trust in the city officials may occur when the system of assistance is too complex. At times, a situation of not sharing information with social welfare centers can occur in order to have a reason not to provide aid. In the case of the interviewed manager of the NGO, trust in social welfare center is increased as "they help us fight for the person". A decrease in the level of trust in social welfare centers may stem from the fact that "employees of social welfare centers should check what is happening with their clients" but they are not doing that.

With respect to the question of whether trust in an employee of another institution depends on personal traits of the employee an answer that "to some extent, simultaneously to nonprofit organizations and social welfare centers" as an employee of NGO would not "for many reasons direct the homeless under care of Ms. X, but would under care of Ms. Y, because the latter is a person who has a positive attitude towards the homeless, does not say 'I was hoping they died', and shows empathy for the homeless". From the point of view of employees of shelters engaged in providing assistance to the homeless, "personnel should be loyal to the people they care for" or "together we fight for a homeless person". Problems are fixed by rules and regulations which the employee must fulfill, that is, "social welfare center employee cannot rationalize the help, while the NGO has such a possibility. For example, if a homeless person lost money on a previous day due to their own fault, a nonprofit organization can withdraw help, whereas a social welfare center cannot withdraw the help. As in a family (i.e., real home) also in the shelter the assistance can be withdrawn for the better good." In the perception of NGOs "the clerk is not a decision taker, since they must provide assistance based on law".

In an answer to the question, is the quality of information obtained by social welfare centers from nonprofit organizations important, the interviewee stated, "the documents show how the clerk will behave, whether that person will try to get rid of the problem as soon as possible, or whether they will try to really assist the homeless. Some clerks phone the NGO for an additional explanation." The interviewee said, "the sentences can show if someone wants to help the homeless. Problems can also arise in the case of clients who have real estate, but due to, for example, mental illness cannot stay there. If the social welfare center employee would trust the nonprofit organization there would be a chance to provide a person with mental illness with housing in social housing for the time being instead of throwing the person out of the shelter due to their available housing".

As to the question regarding the flow of information, the interviewer received an answer "that all depends on the relationship. If there are many procedures, then social welfare centers will not be effective, there must be trust because without it nothing can be done for a homeless person. In our city, the local government created such laws that social welfare centers are no longer effective, and therefore trust is necessary." Furthermore, the question regarding benevolence from employees of cooperating organizations and trust in them received confirmation that it is a significant factor in the relationship. Interviewees said, "one of the factors which can shape trust can be benevolence, for example, if a document is lost, if there is no empathy from the clerk then we can be afraid to try to resolve the issue."

The interviewee emphasized that common values are a very important component of trust in the case of nonprofit organizations and social welfare centers alike as "independently of the organizational membership (religious organization or other) helping the homeless is the most important value and this approach creates trust in the institution. Even during the employee recruitment to nonprofit organizations following a check of professional qualifications, the approach towards a human being is also verified."

Knowledge and competences "are important but they can be supplemented if there is trust and thirst for knowledge, then, we can ensure that the inadequacies will be levelled out."

The frequency of contact is essential as "the employees of our shelter have known employees of other nonprofit organizations for a long time and thanks to this the Assistance Board for the Homeless has been in existence for 25 years, however, the social welfare centers are generally alienated from this." 
According to the NGO manager, the frequency of contact does not increase trust as "sometimes a clerk tries to prove something and says that our NGO has filed 10 applications for social housing and so why he is doing it again on behalf of another colleague, while from the perspective of the NGO, earlier contacts have no connection with the issue at hand."

The promptness is also important as "we can like someone very much but if a social worker does not meet the deadlines, for example, the interview with the homeless person is done at the last legally permitted moment and this causes a three week delay in payment of social benefits, this will cause the trust to be undermined." On the other hand, a situation is possible "when we know that the social welfare center employee is trying hard and this clerk tells us that at the moment they have got a lot of work and they will provide us with a date within a legal deadline, then our trust in that person will not be damaged."

When building trust, emotional aspects are also important as there is "no trust if the assistance is based only on fulfilling rules and regulations but not on actual help. For example, in one nonprofit organization there was a homeless person from another city, and thus that person had a right to apply for a place in social welfare home in that city. Because we trusted the social welfare center employee from another city, as this clerk in warm words described the conditions in social welfare home in that city (we have a beautiful garden, beneficiaries travel ), the NGO employee was able to persuade the homeless that he would have good conditions there, but we had to use emotions not procedures. Such an emotional approach, centered on the human being, makes a connection between satisfaction and cooperation". The interviewee emphasized, "if someone tries and talks about emotions, then even if he is unable to take care of something for the homeless due to legal restrictions, they will say that they we unable to provide the help but feels bad because of it and in that case we will continue to trust that person."

We chose determinants, which can influence trust at the NGOs, based on the literature overview and conducted empirical research, and we decided to use the same set of variables as in the case of social welfare centers, being aware that some variables could mean something different for both types of institutions.

\subsubsection{The Results of the Surveys in the NGOs}

Further support of the results is provided by the analysis of data from surveys from the perspective of the NGOs. The distributions of some important variables from the perspective of the NGOs are presented in the Table 4. Most of the variables have a left skewed distribution, only the variables, trust in relation to social welfare centers' employees (in 2013), and satisfaction from cooperation with other NGOs (in 2018), have a slightly right skewed distribution.

In the case of the NGOs, the average overall assessment of effects and the average overall assessment of the system have slightly improved (from 3.94 to 4.3 and from 3.86 to 4.57 , respectively, on a seven-point scale between 2013 and 2018), but again, the differences cannot be determined in the distributions of these variables based on the Mann-Whitney $U$ test. The evaluation of these effects for the NGOs is slightly larger than it was for the social welfare centers. No differences were found in the distributions of the remaining variables examined between the years analyzed. In the whole sample of NGOs employees, the percentage of females in the NGO sample tested is $76.9 \%$, the percentage of people aged 25 years and below 30 years is $17.3 \%$, aged 30 years and below 40 years is $36.5 \%$, aged 40 years and below 50 years is $25 \%$, and 50 years and below 65 years is $15.4 \%$. In the research sample $19.6 \%$ of people possessed a B.A. education, while $62.7 \%$ had a M.A. 
Table 4. NGOs employee perspectives and descriptive statistics for variables chosen.

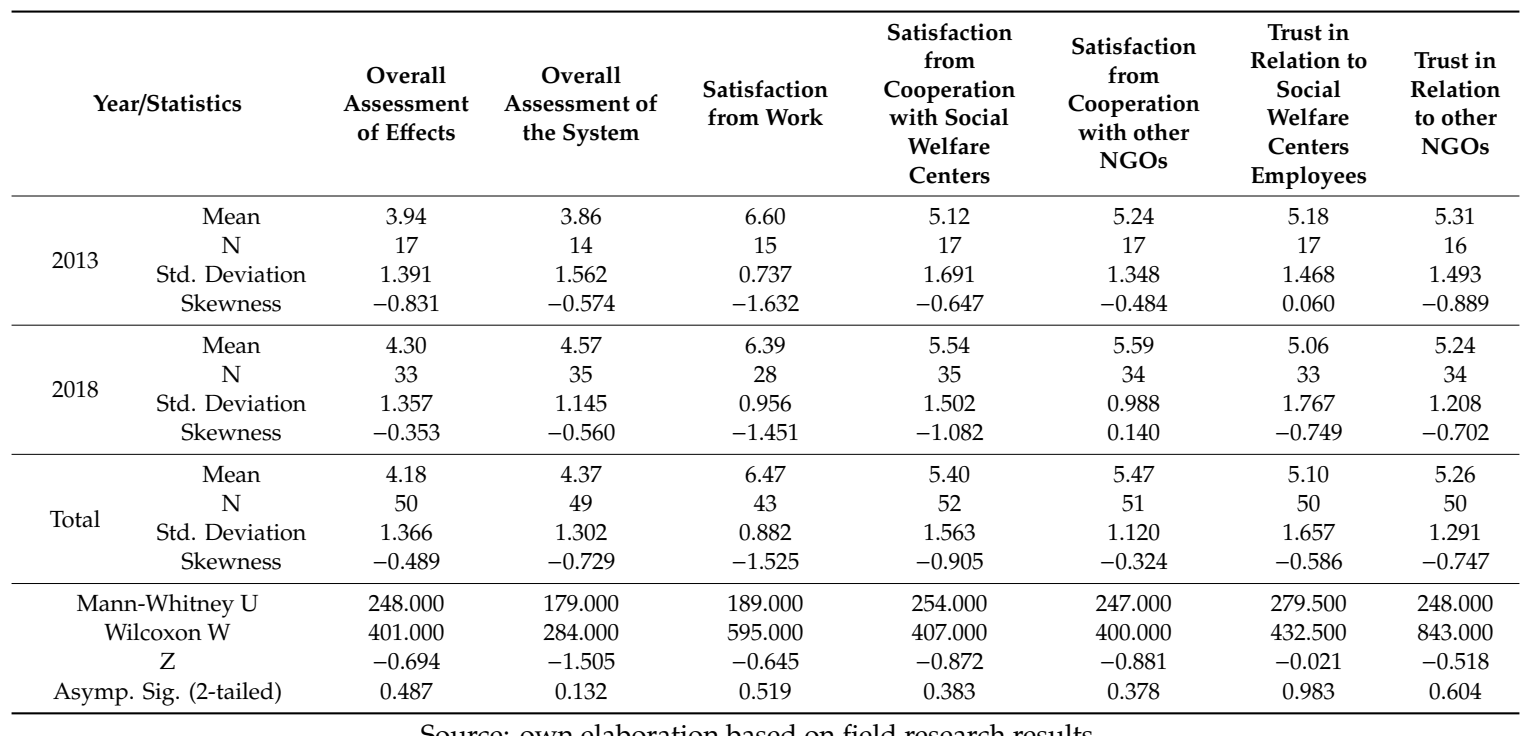

Source: own elaboration based on field research results.

It is surprising how strongly similar the correlation results are in both analyzed periods in the case of, to some extent, dissimilar employees. The responses of the NGO employees regarding their assessment of other institutions, and therefore the correlations between trust and other variables were almost identical in 2013 and 2018.

In the case of assessments of relationships with social welfare centers made from the perspective of the NGOs (see Table 5), trust was correlated with assessment of the ability to obtain information from social welfare centers at the level of 0.618 in 2013 and 0.445 in 2018; assessment of information flow from social welfare centers at the level of 0.617 in 2013 and 0.635 in 2018; assessment of promptness of social welfare centers at the level of 0.733 in 2013 and 0.626 in 2018; assessment of commitment of welfare service centers at the level of 0.533 in 2013 and 0.592 in 2018; assessment of completeness and correctness of documents from social welfare centers at the level of 0.447 and 0.466 , respectively; and assessment of knowledge of employees of welfare service centers at the level of 0.549 and 0.540 , respectively.

Furthermore, very similar results were obtained in correlations among the assessment of NGOs trust and other variables regarding relationships with other NGOs (see Table 6). A correlation with relation to assessment of the possibility to obtain information from other shelters was at a level of 0.532 in 2013 and 0.283 in 2018, however, other variables also proved to be significant, which included the following: assessment of promptness of other shelters at a level of 0.486 in 2013 and 0.613 in 2018; assessment of commitment of other shelters at a level of 0.508 and 0.419 , respectively; and assessment of knowledge of employees of other shelters at a level of 0.627 and 0.458 , respectively. In the case of the variable, assessment of information flow from other shelters, it proved not to be significant in 2013 but significant in the cohort of 2017 to 2018. After combining two research samples this correlation again proved to be significant. A similar result was obtained for the variable, assessment of completeness and correctness of documents from other shelters, which was insignificant in the study conducted in 2013 but significant in the 2018 sample and identically significant when the two research samples were combined. In the case of the NGOs research in 2013, a correlation between trust and a frequency of contact with other shelters proved to be significant at that time, but not significant in 2018, however, significant for the two combined samples. 
Table 5. Trust of NGOs towards the social welfare centers.

\begin{tabular}{|c|c|c|c|c|c|c|c|c|c|c|c|c|c|c|}
\hline Area & Variable & Year & $\mathbf{1}$ & 2 & 3 & 4 & 5 & 6 & 7 & 8 & 9 & 10 & 11 & 12 \\
\hline \multirow{2}{*}{ Trust } & \multirow{2}{*}{$\begin{array}{l}\text { 1. Level of trust in relationships with social welfare } \\
\text { centers }\end{array}$} & 2013 & 1.000 & & & & & & & & & & & \\
\hline & & $\frac{2018}{\text { Overall }}$ & 1.000 & & & & & & & & & & & \\
\hline \multirow{15}{*}{$\begin{array}{c}\text { Organizational } \\
\text { effectiveness (perceived) }\end{array}$} & \multirow{2}{*}{$\begin{array}{l}\text { 2. Assessment of possibility to obtain information from } \\
\text { social welfare centers }\end{array}$} & 2013 & $0.618^{* *}$ & 1.000 & & & & & & & & & & \\
\hline & & 2018 & $0.445^{* *}$ & 1.000 & & & & & & & & & & \\
\hline & \multirow{2}{*}{$\begin{array}{l}\text { 3. Assessment of information flow from social welfare } \\
\text { centers }\end{array}$} & $\begin{array}{l}2013 \\
2018\end{array}$ & $\begin{array}{l}0.617^{* * *} \\
0.635^{* *}\end{array}$ & $0.709^{* * *} 0.617^{* *}$ & $\begin{array}{l}1.000 \\
1.000\end{array}$ & & & & & & & & & \\
\hline & & Overall & $0.623^{* *}$ & $0.623^{* *}$ & 1.000 & & & & & & & & & \\
\hline & \multirow{3}{*}{ 4. Assessment of promptness of social welfare centers } & 2013 & $0.733^{* *}$ & $0.621^{* *}$ & $0.782^{* *}$ & 1.000 & & & & & & & & \\
\hline & & 2018 & $0.626^{* *}$ & $0.557^{* *}$ & $0.690^{* *}$ & 1.000 & & & & & & & & \\
\hline & & Overall & $0.648^{* *}$ & $0.565^{* *}$ & $0.724^{* *}$ & 1.000 & & & & & & & & \\
\hline & \multirow{2}{*}{$\begin{array}{l}\text { 5. Assessment of commitment of welfare service } \\
\text { centers }\end{array}$} & 2013 & $0.533^{* *}$ & $0.529^{* *}$ & $0.552^{* *}$ & $0.606^{* *}$ & 1.000 & & & & & & & \\
\hline & & 2018 & $0.592^{* *}$ & $0.533^{* *}$ & $0.678^{* *}$ & $0.581^{* *}$ & 1.000 & & & & & & & \\
\hline & \multirow{3}{*}{$\begin{array}{l}\text { 6. Assessment of completeness and correctness of } \\
\text { documents from social welfare centers }\end{array}$} & $\frac{\text { Overall }}{2013}$ & 0.571 * 047 & $0.537^{* *} * 3$ & $0.622^{* *}$ & $0.589^{* *}$ & $\begin{array}{r}1.000 \\
0.557^{* *}\end{array}$ & & & & & & & \\
\hline & & 2018 & $0.466 * *$ & $0.313^{*}$ & $0.400^{* *}$ & $0.526^{* *}$ & $\frac{0.551^{* *}}{\left.0.251^{*}\right)}$ & 1.000 & & & & & & \\
\hline & & Overall & $0.456^{* *}$ & 0.386 ** & $0.379^{* *}$ & $0.459^{* *}$ & $\frac{0.311 /}{0.388^{* *}}$ & 1.000 & & & & & & \\
\hline & \multirow{3}{*}{$\begin{array}{l}\text { 7. Assessment of knowledge of employees of welfare } \\
\text { service centers }\end{array}$} & 2013 & $0.549^{* *}$ & $0.471^{*}$ & $0.476^{*}$ & $0.581^{* *}$ & $0.793^{* *}$ & $0.479 *$ & 1.000 & & & & & \\
\hline & & 2018 & $0.540^{* *}$ & 0.540 ** & $0.521^{* *}$ & 0.546 ** & $0.621^{* *}$ & $0.418^{* *}$ & 1.000 & & & & & \\
\hline & & Overall & $0.541^{* *}$ & $0.521 * *$ & $0.501 * *$ & $0.559^{* *}$ & $0.673 * *$ & $0.437^{* *}$ & 1.000 & & & & & \\
\hline \multirow{3}{*}{ Contact } & \multirow{3}{*}{ 8. Frequency of contact with social welfare centers } & 2013 & 0.091 & -0.061 & -0.095 & -0.071 & -0.176 & 0.130 & -0.085 & 1.000 & & & & \\
\hline & & 2018 & -0.094 & 0.157 & -0.049 & -0.053 & -0.015 & -0.028 & -0.014 & 1.000 & & & & \\
\hline & & Overall & -0.041 & 0.088 & -0.084 & -0.065 & -0.080 & 0.024 & -0.039 & 1.000 & & & & \\
\hline \multirow{10}{*}{ Outcomes perceived } & \multirow{3}{*}{$\begin{array}{l}\text { 9. Satisfaction from cooperation with welfare service } \\
\text { centers }\end{array}$} & 2013 & $0.805^{* *}$ & $0.643^{* *}$ & $0.690^{* *}$ & $0.720^{* *}$ & 0.601 ** & $0.374\left(^{*}\right)$ & 0.598 ** & -0.059 & 1.000 & & & \\
\hline & & 2018 & $0.687^{* *}$ & $0.539 * *$ & $0.634^{* *}$ & $0.528^{* *}$ & $0.675 * *$ & $0.271(*)$ & 0.599 ** & -0.229 & 1.000 & & & \\
\hline & & Overall & $0.718^{* *}$ & 0.567 ** & $0.625^{* *}$ & $0.581^{* *}$ & $0.644^{* *}$ & $0.332^{* *}$ & $0.586^{* *}$ & -0.162 & 1.000 & & & \\
\hline & \multirow[t]{2}{*}{ 10. Satisfaction from work in the shelter } & 2018 & $0.311\left(^{*}\right)$ & $0.299\left(^{*}\right)$ & 0.157 & 0.269 & 0.239 & 0.122 & 0.256 & 0.040 & $0.303\left(^{*}\right)$ & 1.000 & & \\
\hline & & Overall & $0.254\left(^{*}\right)$ & $0.244\left(^{*}\right)$ & 0.119 & 0.159 & $0.274^{*}$ & 0.223 & $0.257\left(^{*}\right)$ & 0.043 & $0.223(*)$ & 1.000 & & \\
\hline & \multirow{3}{*}{$\begin{array}{l}\text { 11. Overall assessment of the homeless assistance } \\
\text { system in Warsaw }\end{array}$} & 2013 & 0.347 & 0.284 & 0.224 & $0.400\left(^{*}\right)$ & $\left.0.380^{*}\right)$ & 0.323 & 0.385 & 0.015 & 0.299 & -0.234 & 1.000 & \\
\hline & & 2018 & 0.218 & $0.383^{* *}$ & $0.341^{*}$ & $0.337^{*}$ & 0.401 ** & 0.092 & $0.473^{* *}$ & -0.134 & 0.351 * & $0.280^{*}$ & 1.000 & \\
\hline & & Overall & $0.255^{*}$ & $0.338^{* *}$ & $0.245^{*}$ & $0.288^{*}$ & $0.405^{* *}$ & 0.172 & $0.430^{* * *}$ & -0.071 & $0.350^{* *}$ & 0.119 & 1.000 & \\
\hline & \multirow{2}{*}{$\begin{array}{l}\text { 12. Overall assessment of effects of the homeless } \\
\text { assistance system in Warsaw (in terms of getting out of } \\
\text { homelessness) }\end{array}$} & 2013 & 0.196 & $0.387\left(^{*}\right)$ & 0.315 & $0.357(*)$ & $0.363\left(^{*}\right)$ & $0.358\left(^{* *}\right)$ & 0.269 & -0.282 & 0.193 & -0.064 & 0.659 ** & 1.000 \\
\hline & & 2018 & 0.165 & 0.181 & 0.207 & 0.183 & 0.156 & 0.013 & $0.389^{* *}$ & -0.160 & $0.261(*)$ & 0.211 & $0.533^{* *}$ & 1.000 \\
\hline
\end{tabular}

Correlation (two-sided) significant at a level: ${ }^{* *} 0.01,{ }^{*} 0.05,{ }^{(*)} 0.10$; Source: own elaboration based on field research results. 
Table 6. Trust of NGOs towards other NGOs (shelters).

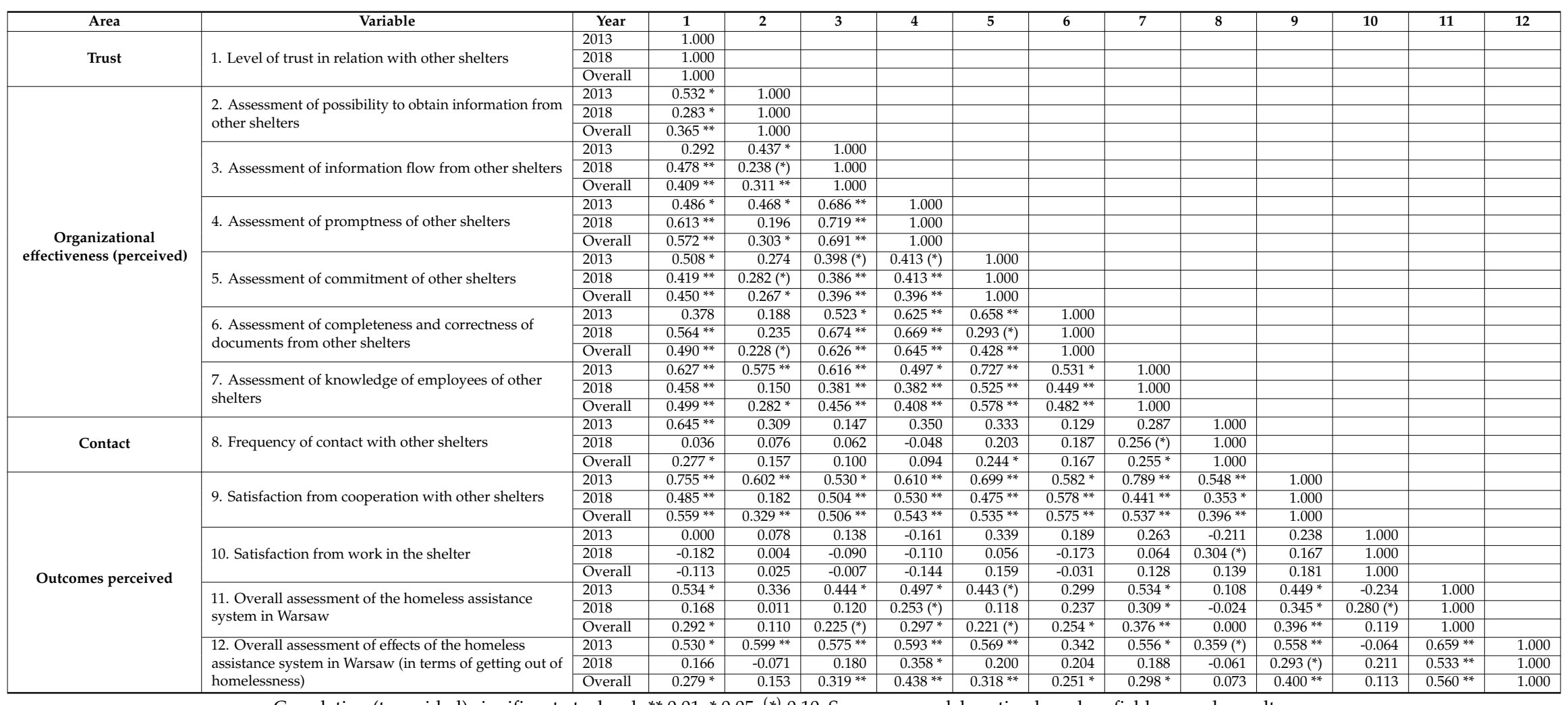

Correlation (two-sided) significant at a level: ${ }^{* *} 0.01,{ }^{*} 0.05,{ }^{* *} 0.10$; Source: own elaboration based on field research results. 
Furthermore, it should be emphasized that some correlations that were insignificant in the second phase of the study, could be treated as significant at a less conservative level of $10 \%$. Trust proved not to be correlated with control variables such as gender, age, and education in both research samples at both points in time. Therefore, we conclude that control variables had no impact on differentiation in the research sample. The sample, with respect to control variables such as gender and position, was homogeneous, as the sample included mostly women in managerial roles at the NGOs and social workers at the social welfare centers. Additional control variables used in the study included the following: satisfaction from work, satisfaction from cooperation with other social welfare centers in Warsaw, satisfaction from cooperation with NGOs, overall assessment of effects, and overall assessment of the system. Correlations between trust and perceived outcome variables proved, in most cases, to be insignificant which allowed us to conduct the analysis without dividing the sample. The analysis has shown that due to the difficulty of the serviced client, it is not possible to obtain great and quick outcomes, and therefore (as expected) trust is not correlated with perceived outcome.

Figure 3 presents a summary of correlations among trust from the perspective of the NGOs and variables pertaining to perceived organizational effectiveness including the variable "frequency of contact".

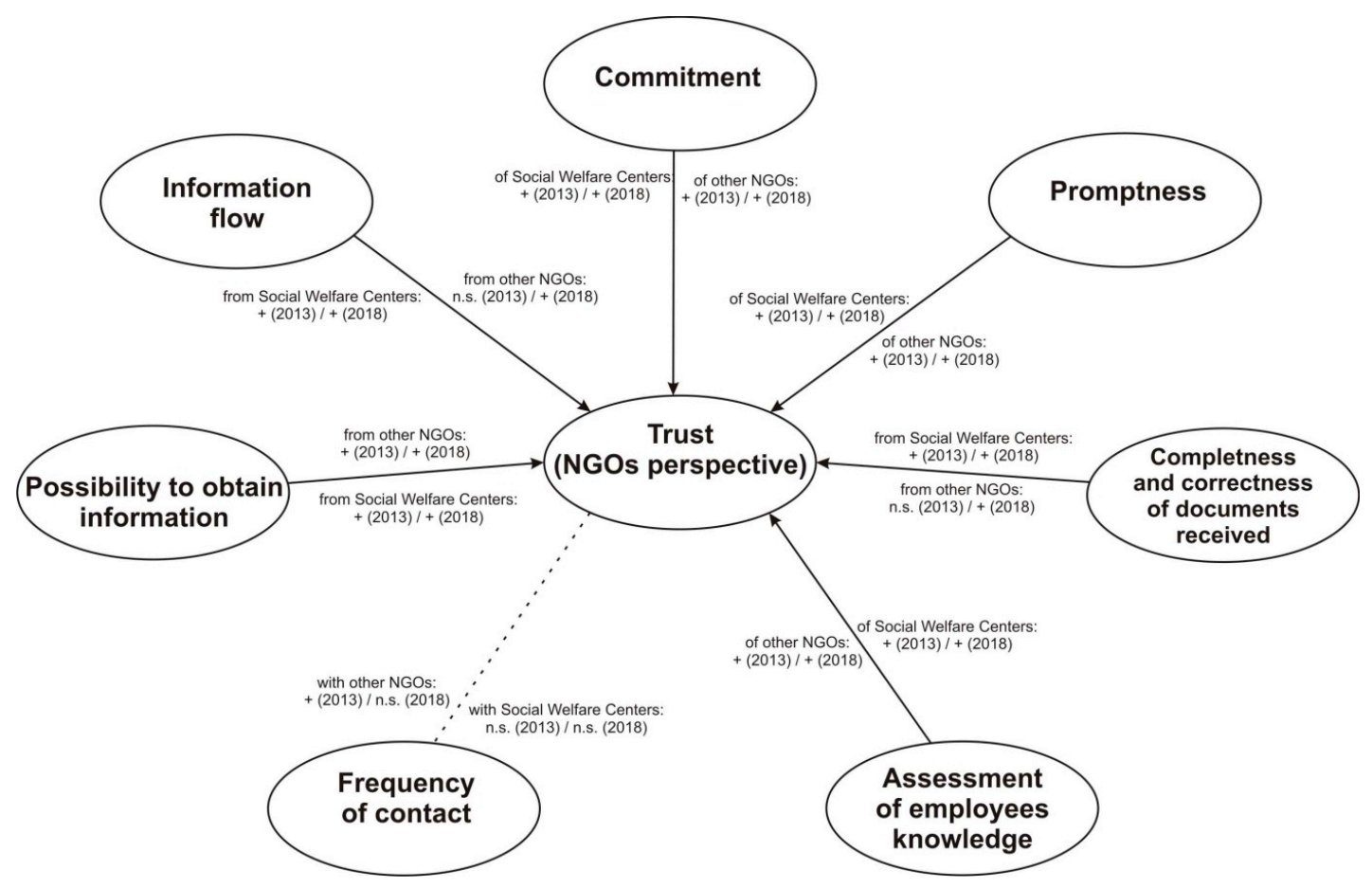

Figure 3. Correlations between trust and other variables (NGOs perspective). Source: own elaboration.

A fixed correlation between trust from the perspective of the NGOs and perceived organizational effectiveness in relation to social welfare centers is clearly visible. Nonetheless, the relationship between trust from the perspective of the NGOs and the frequency of contact shows that such a correlation generally does not exist. Figure 4 shows correlations among trust from the perspective of the NGOs and variables pertaining to the perceived outcomes of the network. All correlations prove to be statistically significant only in the case of the relationship between trust and satisfaction from cooperation. 


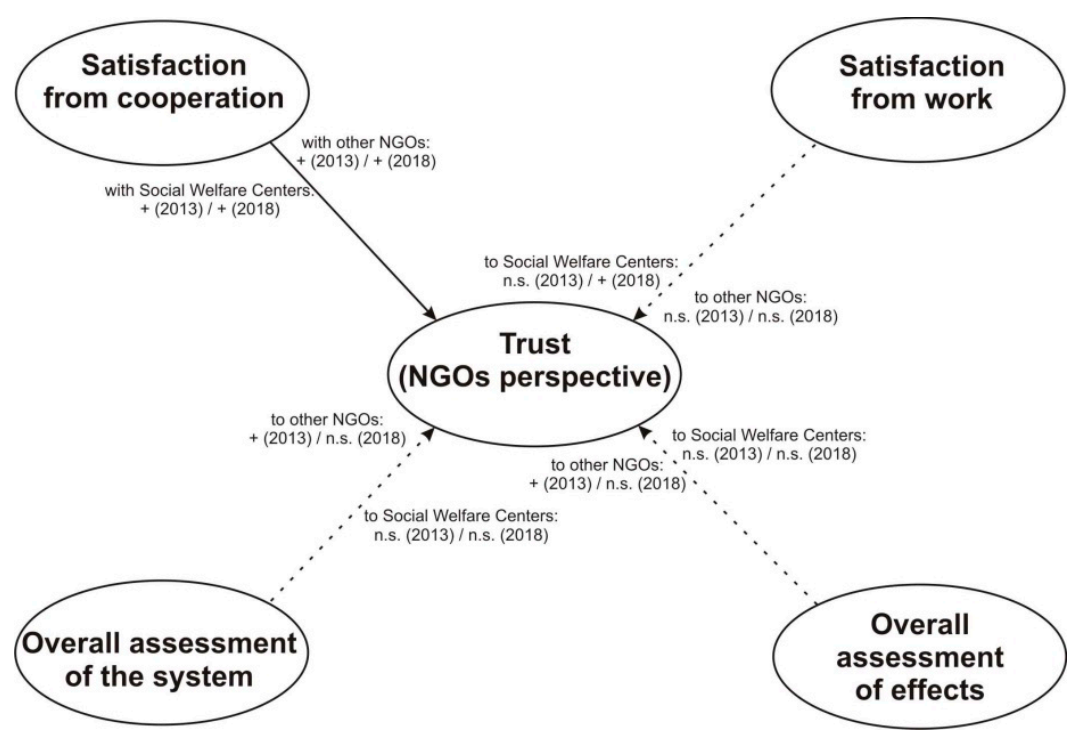

Figure 4. Correlations between trust and outcomes perceived (NGOs perspective). Source: own elaboration.

\subsection{Hypotheses Validation}

Research hypotheses were validated. There are no grounds to reject the hypothesis that there is a relationship between interorganizational trust and perceived organizational effectiveness of other actors in the network. To conclude, the results of longitudinal studies done in 2013 and from 2017 to 2018 , in the case of both NGOs and social welfare centers show that there are reasons to believe that in the case of public service delivery networks there are fixed correlations among interorganizational trust and variables such as the ability to obtain information, information flow, commitment, promptness, completeness and correctness of documents received, and assessment of employees knowledge. On the contrary, the correlation between trust and frequency of contact is not significant.

The hypothesis of a relationship between interorganizational trust and frequency of contact should be, therefore, rejected. Nevertheless, in the case of the NGOs' this correlation may exist to some extent because in one of the analyzed samples such a correlation was statistically significant. This stems from the fact that collaboration between the NGOs is stronger than between the NGOs and social welfare centers. In this case, the frequency of contact can be connected with a higher intensity of interorganizational trust. The interviews conducted with employees of the NGOs revealed the reason for contact and trust and also includes benevolence among collaborating actors. A summary of the results obtained pertaining to perceived organizational effectiveness of other actors in the collaborative network and frequency of contact is presented in Figure 5.

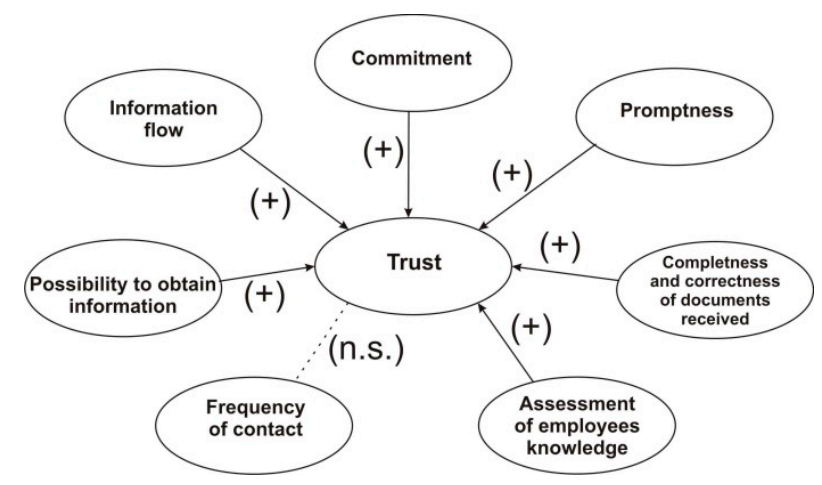

Figure 5. Correlations among trust and other variables independent of institutions studied. Source: own elaboration. 
To analyze the hypothesis regarding a positive correlation between interorganizational trust and perceived outcomes, the results seem varied. This may be a result of specificity of homelessness, where the exit from homelessness as an outcome, is not always desired or even possible.

Correlations among interorganizational trust and network management outcomes and outcomes perceived (see Figure 6) were positive at one point in time or generally statistically insignificant. Only in the case of correlation between trust and satisfaction from cooperation, was the positive correlation in both research samples confirmed.

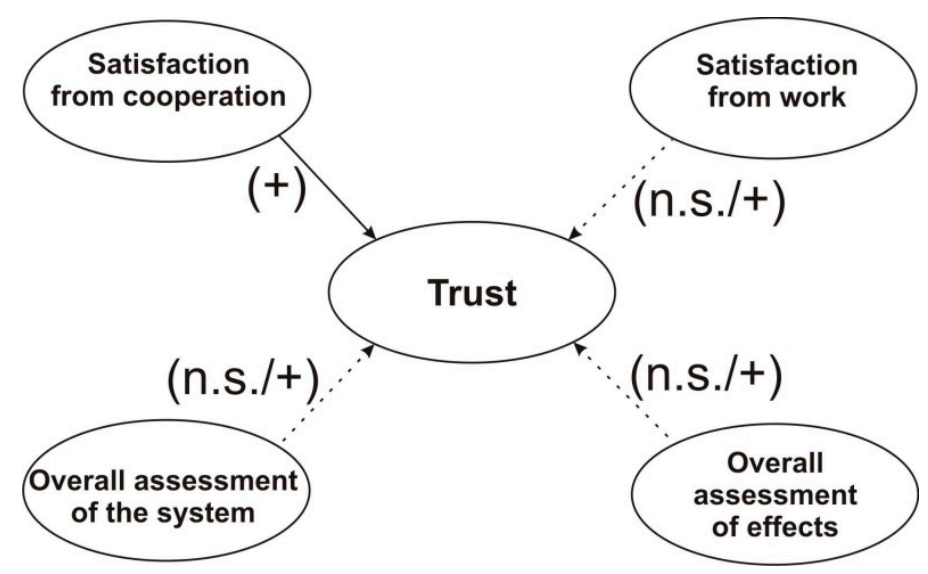

Figure 6. Correlations among trust and other variables independent of institutions studied. Source: own elaboration.

When analyzing the correlation between interorganizational trust and satisfaction from work, the results were positive, but in some cases not statistically significant. The study of this relationship should be repeated in the future on a different research sample. However, the correlation between interorganizational trust and overall assessment of the system, most of the time, was not statistically significant. Significance appeared only in the case of trust in the NGOs both from the perspective of other NGOs and social welfare centers. The same was valid in the case of the correlation between trust in the NGOs and overall assessment of the effects of the homeless assistance system. The reason for this may be that the biggest responsibility for working with clients in the area of homelessness is placed on the shoulders of nonprofit organizations. These organizations are most often held accountable for people leaving homelessness, while the social welfare centers are more accountable for organizational effectiveness.

\section{Discussion and Conclusions}

The results obtained show that, in our research study, interorganizational trust is correlated with perceived interorganizational effectiveness of other actors in a collaborative network. It cannot be determined if in the research sample of social welfare centers and NGOs, a relationship between trust and perceived outcomes of the network exists. This may be due to the specificity of a public service delivery network that provides services to demanding clients where it is often extremely difficult to ensure outcomes such as the exit from homelessness. Many clients of the system have been in a state of homelessness for a long time, have weak health, are elderly, and are addicted to alcohol. In such a system, individual employees, in social welfare centers and NGOs alike, can build mutual relationships based on organizational effectiveness. Fast reaction and information sharing, as well as engagement and completeness in preparing documents clearly add to building interorganizational trust. They are, thus, a necessary precondition of a network that is functioning well. Therefore, we are talking about process-oriented trust, not result-oriented trust. In our study, we conclude that the higher the organizational effectiveness, the greater the trust. Process outcomes gain meaning as an element of network management. 
An important conclusion of our study is that when conducting an assessment in public service delivery networks of variables such as trust, organizational effectiveness of networks cannot be omitted. In the provision of some public services, especially those in which spectacular and easily attainable outcomes are rare, organizational effectiveness becomes much more important and can determine trust instead of system or community level outcomes. It is also important to "obtain small improvements in outcomes" when working with a homeless person. Moreover, if employees of other entities in a collaborative service delivery network are effective in attaining these incremental, day-to-day successes, a higher level of trust is possible.

On the basis of the analyzed research sample, it has been found, in particular, that there is a correlation among interorganizational trust and variables which form interorganizational effectiveness (the possibility to obtain information, the flow of information, promptness, commitment, completeness and correctness of documents received, and assessment of other organizations' employee knowledge). This means that building trust in interorganizational networks based on collaboration requires applying rules and norms known to insiders of the organizations. Even if the outcome as an exit from homelessness is challenging, the employees of a public service delivery network can highly value effectiveness of the process of service delivery, and therefore maintain a high level of interorganizational trust. This has an important economic implication and can be important guidance for people undertaking decisions regarding collaborative arrangements. Thus, process-oriented trust becomes increasingly important and it can compensate for results-oriented trust (also because of "wicked problems"). The actors of the system are not always able to achieve an expected outcome, but they work on their clients' behalf, and trust in this case applies to activities and processes rather than outcomes of the whole system. Understanding of these interrelationships can be very helpful in an economic debate on improving operations of public service delivery networks. Findings and suggestions of this study are summarized and presented in Table 7.

Our research, has several limitations. Firstly, it is based on a sample of nonprofit organizations operating in the City of Warsaw and Warsaw's Social Welfare Centers. While such an approach gives a unique insight into various actors' perceptions and it provides a deeper understanding of a single societal problem, the great benefit is that this study has been based on a variety of data sources and we had access to a full dataset. Furthermore, since the longitudinal research was applied and the results repeated at two different points in time, this weakness has been overcome. Next, we are aware that not all determinants of trust, which stem from the literature review, have been considered, however, this was due to the specificity of our research sample and results of in-depth interviews. We plan to consider other determinants of trust in further research. In addition, our research is conducted in light of economic theory, however possibly a broader psychological and sociological approach should be undertaken, but still with interorganizational effectiveness included. Finally, in order to expand the study, more variables could have been used, but it would have required more expanded questionnaires. We did not want to overuse the patience of the collaborative network employees, however, in the future, research could be expanded in this direction. Our results should be considered while keeping these limitations in mind.

It seems clear that in the case of the most difficult and complex social services, organizational effectiveness is at its forefront and trust in actors in the network depends on it. Frequency of contact does not have to be connected with it and depends on various variables. An employee can contact someone when the need arises and trust them, but the employee can also contact someone often but still not have a lot of trust in them. Results of this study can be useful for making improvements in collaborative network performance measurements and confirm that interorganizational effectiveness is still an important factor in the analysis of networks. 
Table 7. Findings and suggestions.

\begin{tabular}{|c|c|c|}
\hline & Findings & Suggestions \\
\hline 1 & $\begin{array}{l}\text { A correlation exists between } \\
\text { interorganizational effectiveness and } \\
\text { interorganizational trust. }\end{array}$ & $\begin{array}{l}\text { In public service delivery networks, it is impossible to } \\
\text { resign from care for interorganizational effectiveness. }\end{array}$ \\
\hline 2 & $\begin{array}{l}\text { A correlation exists between satisfaction } \\
\text { from cooperation and interorganizational } \\
\text { trust, independent of the perspective } \\
\text { undertaken in a public service delivery } \\
\text { collaborative network. }\end{array}$ & $\begin{array}{l}\text { Without satisfaction from cooperation, building of } \\
\text { interorganizational trust could be difficult. }\end{array}$ \\
\hline 3 & $\begin{array}{l}\text { Higher interorganizational effectiveness } \\
\text { means higher interorganizational trust. }\end{array}$ & $\begin{array}{l}\text { Interorganizational trust can be built, among others, } \\
\text { on the basis of dimensions of organizational } \\
\text { effectiveness. }\end{array}$ \\
\hline 4 & $\begin{array}{l}\text { The quality of contact is more important } \\
\text { than frequency of contact in public service } \\
\text { delivery networks. }\end{array}$ & $\begin{array}{l}\text { First contact with employees of other institutions is } \\
\text { crucial. At times, higher frequency of contact may } \\
\text { reveal lack of knowledge or incompetence of } \\
\text { employees of other institutions. On the other hand, if } \\
\text { there is a good will and common values on both sides } \\
\text { then there is a possibility to improve trust. }\end{array}$ \\
\hline 5 & $\begin{array}{l}\text { Assessment of the service delivery process } \\
\text { is more important and independent of } \\
\text { assessment of perceived outcomes from the } \\
\text { point of view of organizations engaged in a } \\
\text { public service delivery network providing } \\
\text { services to "difficult clients". }\end{array}$ & $\begin{array}{l}\text { When building interorganizational trust during the } \\
\text { service delivery process, trust is especially essential } \\
\text { in the case of more demanding "difficult client" and } \\
\text { in the case of outcomes difficult to attain. }\end{array}$ \\
\hline 6 & $\begin{array}{l}\text { Even if the goals are differently perceived } \\
\text { by different organizations and effectiveness } \\
\text { means different things to them, the } \\
\text { correlations among interorganizational trust } \\
\text { and organizational variables are similar in } \\
\text { both research samples of employees. }\end{array}$ & $\begin{array}{l}\text { Categories such as the possibility to obtain } \\
\text { information, flow of information, promptness, } \\
\text { commitment, completeness and correctness of } \\
\text { documents received, and assessment of other } \\
\text { organizations' employee knowledge are essential in } \\
\text { trust building from the perspective of a public service } \\
\text { delivery network. It stems from the fact that } \\
\text { organizations cannot resign from ensuring } \\
\text { interorganizational effectiveness when they want to } \\
\text { retain a high level of trust in relationships with } \\
\text { collaborating actors. }\end{array}$ \\
\hline
\end{tabular}

Source: own elaboration.

Author Contributions: Conceptualization, K.O., P.M., and A.K.; methodology, P.M., K.O., and A.K.; formal analysis, P.M.; data analysis, P.M.; investigation, P.M., K.O., and A.K.; project administration, P.M.; writing-original draft preparation, P.M. and A.K.; writing-review, P.M. and K.O.; writing-editing, P.M. and A.K.; visualization, P.M.; supervision, K.O.; funding acquisition, P.M. and K.O.

Funding: This research was supported by a Research Grant no: 2015/19/D/HS4/01968 from the National Science Centre, Poland.

Conflicts of Interest: The authors declare no conflict of interest.

\section{References}

1. Klijn, E.H.; Edelenbos, J.; Stein, B. Trust in Governance Networks: Its Impacts on Outcomes. Adm. Soc. 2010, 42, 193-221. [CrossRef]

2. Berman, E.M. Productivity in Public and Nonprofit Organizations. Strategies and Techniques; SAGE Publications: Thousand Oaks, CA, USA, 1998.

3. McNabb, D.E. Quantitative and Qualitative Approaches.Research Methods in Public Administration and Nonprofit Management; M. E. Sharpe: Armonk, NY, USA, 2002; p. 213.

4. Tashakkori, A.; Creswell, J.W. The New Era of Mixed Methods. J. Mix. Methods Res. 2007, 1, 3-4. [CrossRef]

5. Kendall, M.G. Rank Correlation Methods; Hafner Publishing Co.: New York, NY, USA, 1955. 
6. Kożuch, B.; Jabłoński, A. The Strategic Hybrids of Water Supply Companies as an Effective Management Tool. Sustainability 2018, 10, 4450. [CrossRef]

7. Schoorman, D.F.; Mayer, R.C.; Davis, J.H. An Integrative Model of Organizational Trust: Past, Present, and Future. Acad. Manag. Rev. 2007, 32, 344-354. [CrossRef]

8. Deutsch, M. Trust and suspicion. J. Confl. Resolut. 1958, 2, 265-279. [CrossRef]

9. Sako, M. Price, Quality, And Trust: Inter-Firm Relations in Britain and Japan; Cambridge University Press: Cambridge, UK, 1992.

10. Mayer, R.C.; Davis, J.H.; Schoorman, F.D. An Integrative Model of Organizational Trust. Acad. Manag. Rev. 1995, 20, 709. [CrossRef]

11. Bhattacharya, S.; Boot, A.; Thakor, A. The Economics of Bank Regulation. J. Money Credit Bank. 1998, 30, 745-770. [CrossRef]

12. Paliszkiewicz, J. Zaufanie w Zarzadzaniu; Wydawnictwo Naukowe PWN: Warszawa, Poland, 2013.

13. Rousseau, D.M.; Sitkin, S.B.; Burt, R.S.; Camerer, C. Not so different after all: A cross-discipline view of trust. Acad. Manag. Rev. 1998, 23, 393-404. [CrossRef]

14. Rempel, J.K.; Holmes, J.G.; Zanna, M.P. Trust in close relationships. J. Personal. Soc. Psychol. 1985, $49,95$. [CrossRef]

15. De Oliveira, G.F.; Rabechini, R., Jr. Stakeholder management influence on trust in a project: A quantitative study. Int. J. Proj. Manag. 2019, 37, 131-144. [CrossRef]

16. Strahorn, S.; Gajendran, T.; Brewer, G. The influence of trust in traditional contracting: Investigating the "lived experience" of stakeholders. Constr. Econ. Build. 2015, 15, 81. [CrossRef]

17. Hartman, F.T. Chapter 13: The role of trust in project management. In The Frontiers of Project Management Research; Pinto, J.K., Cleland, D.I., Slevin, D.P., Eds.; Project Management Institute, Inc.: Newton Square, PA, USA, 2003.

18. Aubert, B.A.; Kelsey, B.L. The Illusion of Trust and Performance; Cirano: Amiens, France, 2000.

19. Harrison, V.S.; Xiao, A.; Ott, H.K.; Bortree, D. Calling all volunteers: The role of stewardship and involvement in volunteer-organization relationships. Public Relat. Rev. 2017, 43, 872-881. [CrossRef]

20. Hernandez, M. Toward an understanding of the psychology of stewardship. Acad. Manag. Rev. 2012, 37, 172-193. [CrossRef]

21. Moran, K.; Mallia, T. Wholly engaged: Integrating volunteer and donor programs. In Volunteer Engagement 2.0: Ideas and Insights Changing the World; Rosenthal, R.J., Ed.; John Wiley \& Sons: Hoboken, NJ, USA, 2015.

22. McEvily, B.; Perrone, V.; Zaheer, A. Trust as an organizing principle. Organ. Sci. 2003, 14, 91-103. [CrossRef]

23. Elangovan, A.R.; Auer-Rizzi, W.; Szabo, E. Why don't I trust you now? An attributional approach to erosion of trust. J. Manag. Psychol. 2007, 22, 4-24. [CrossRef]

24. Edelenbos, J.; Klijn, E.H. Trust in Complex Decision-Making Networks. A Theoretical and Empirical Exploration. Adm. Soc. 2007, 39, 25-50. [CrossRef]

25. Pate, J.; Beaumont, P.; Stewart, S. Trust in senior management in the public sector. Empl. Relat. 2007, 29, 458-468. [CrossRef]

26. Molina-Morales, F.X.; Martinez-Fernandez, M.T.; Torlo, V.J. The dark side of trust: The benefits, costs and optimal levels of trust for innovation performance. Long Range Plan. 2011, 44, 118-133. [CrossRef]

27. Dirks, K.T. Trust in leadership and team performance: Evidence from NCAA basketball. J. Appl. Psych. 2000, 85, 1004-1012. [CrossRef]

28. Kożuch, B.; Sienkiewicz-Małyjurek, K.; Lenart-Gansiniec, R. Public trust and organizational learning in academic institutions in Poland. In Managing Public Trust; Kożuch, B., Magala, S.J., Paliszkiewicz, J., Eds.; Palgrave Macmillan: Basingstoke, UK, 2018.

29. Santana, A.; Vaccaro, A.; Wood, D.J. Ethics and the Networked Business. J. Bus. Ethics 2009, 90, 661-681. [CrossRef]

30. Eisenberger, R.; Huntington, R.; Hutchinson, S.; Sowa, D. Perceived Organizational Support. J. Appl. Psych. 1986, 71, 500-507. [CrossRef]

31. Ebel, P.; Clement, U.; Moller, H. Socializing employees' trust in the organization: An exploration of apprentices' socialization in two highly trusted companies. Hum. Resour. Manag. J. 2012, 22, 343-359. [CrossRef]

32. Brenkert, S.B.; Bamberger, P.A.; Sonnenstuhl, W.J. Driven to drink: Managerial control, work-related risk factors, and employee problem drinking. Acad. Manag. J. 2002, 45, 637-658. 
33. Burton, S.K. Without trust, you have nobody: Effective employee communication for today and tomorrow. Public Relat. Strateg. 2006, 12, 32-36.

34. Willemyns, M.; Gallois, C.; Callan, V.J. Trust me, I'm your boss. Trust and power in supervisor-supervisee communication. Int. J. Hum. Resour. Manag. 2003, 14, 117-127. [CrossRef]

35. Eisenberger, R.; Stinglhamber, F.; Vandenberghe, C.H.; Sucharski, I.; Rhoades, L. Perceived Supervisor Support: Contributions to Perceived Organizational Support and Employee Retention. J. Appl. Psychol. 2002, 87, 565-573. [CrossRef] [PubMed]

36. Lee, M.; Koh, J. Is empowerment really a new concept? Hum. Resour. Manag. 2001, 12, 684-695. [CrossRef]

37. Lincoln, N.D.; Travers, C.; Ackers, P.; Wilkinson, A. The meaning of empowerment: The interdisciplinary etymology of a new management concept. Int. J. Manag. Rev. 2002, 4, 271-290. [CrossRef]

38. Stoner, J.; Freeman, E.; Gilbert, D. Kierowanie (Management); PWE: Warszawa, Poland, 2001.

39. Siergrist, M.; Earle, T.C.; Gutscher, H. Test of trust and confidence model in the applied context of electromagnetic field (EFM) risk. Risk Anal. Int. J. 2003, 4, 705-716. [CrossRef]

40. Bugdol, M. Wymiary i Problem Zarzadzania Organizacja Oparta na Zaufaniu; Wydawnictwo Uniwersytetu Jagiellońskiego: Krakow, Poland, 2010.

41. Rhodes, R. Understanding Governance: Policy Networks, Governance, Reflexivity and Accountability; Open University Press: London, UK, 1997.

42. Kooiman, J. Modern Governance: New Government-Society Interactions; Sage Publications: London, UK, 1993.

43. Kickert, W.J.M.; Klijn, E.H.; Koppenjan, J.F.M. Managing Complex Networks: Strategies for the Public Sector; Sage Publications: London, UK, 1997.

44. Keast, R. Network Theory Tracks and Trajectories: Where from, Where to? In Network Theory in the Public Sector; Building New Theoretical Frameworks; Keast, R., Mandell, M., Agranoff, R., Eds.; Routledge: New York, NY, USA, 2014; pp. 15-32.

45. Goldsmith, S.; Eggers, W. Governing by Network: The New Shape of the Public Sector; The Brookings Institution: Washington, DC, USA, 2004.

46. Koppenjan, J.F.; Klijn, E.H. Managing Uncertainties in Networks; Routledge: London, UK, 2004.

47. Sorensen, E.; Torfing, J. Theories of Democratic Network Governance; Palgrave Macmillan: Basingstoke, UK, 2007.

48. Provan, K.G.; Milward, H.B. A Preliminary Theory of Interorganizational Network Effectiveness-A Comparative Study of four Community Mental-Health Systems. Adm. Sci. Q. 1995, 40, 169-190. [CrossRef]

49. Keast, R.; Mandell, M.R.; Brown, K.; Woolcock, G. Network structures: Working differently and changing expectations. Public Adm. Rev. 2004, 64, 363-371. [CrossRef]

50. Agranoff, R. Managing Collaborative Performance: Changing the Boundaries of the State? Public Perform. Manag. Rev. 2005, 29, 18-45.

51. Mandell, M.; Keast, R. Evaluating network arrangements. Toward Revised Performance Measures. Public Perform. Manag. Rev. 2007, 30, 574-597. [CrossRef]

52. Koppenjan, J. Creating a playing field for assessing the effectiveness of network collaboration by performance measures. Public Manag. Rev. 2008, 10, 699-714. [CrossRef]

53. Cristofoli, D.; Markovic, J.; Meneguzzo, M. Governance, management and performance in public networks: How to be successful in shared-governance networks. J. Manag. Gov. 2014, 18, 77-93. [CrossRef]

54. O'Leary, R.; Gerard, C.; Keast, R.; Mandell, M.P.; Voets, J. Collaboration and Performance: Introduction to Symposium on Collaboration. Public Perform. Manag. Rev. 2015, 38, 573-577. [CrossRef]

55. Agostino, D.; Arnaboldi, M. Performance measurement systems in public service networks. The what, who, and how of control. Financ. Account. Manag. 2018, 34, 103-116. [CrossRef]

56. Cepiku, D. Network Performance: Toward a Dynamic Multidimensional Model. In Network Theory in the Public Sector; Building New Theoretical Frameworks; Keast, R., Mandell, M., Agranoff, R., Eds.; Routledge: New York, NY, USA, 2014; pp. 174-192.

57. Koliba Ch Meek, J.W.; Zia, A. Governance Networks in Public Administration and Public Policy; CRC Press: Boca Raton, FL, USA, 2011.

58. Klijn, E.-H.; Koppenjan, J. Governance Networks in the Public Sector; Routledge: New York, NY, USA, 2016.

59. Weiping, J.; Xianbo, Z.; Jian, Z. (Dis) Trust, Control, and Project Success: From a Chinese Project Owner's Perspective. Sustainability 2017, 9, 1936. [CrossRef] 
60. Doney, P.M.; Cannon, J.P. An examination of the nature of trust in buyer-seller relationships. J. Mark. 1997, 61, 35-51.

61. McGuire, M.; Agranoff, R. The limitations of public management networks. Public Adm. 2011, 89, $265-284$. [CrossRef]

62. Vaccaro, I.G.; Jansen, J.J.; Van Den Bosch, F.A.; Volberda, H.W. Management Innovation and Leadership: The Moderating Role of Organizational Size. J. Manag. Stud. 2012, 49, 28-51. [CrossRef]

63. Williamson, O.E. Calculated trust, a reply to Craswell's comment on Williamson. J. Law Econ. 1993, 36, 501-502. [CrossRef]

64. Mizrahi, S.; Vigoda-Gadot, E.; Cohen, N. Trust, participation, and performance in public administration. An empirical examination of health services in Israel. Public Perform. Manag. Rev. 2009, 33, 7-33. [CrossRef]

65. Meier, K.J.; O'Toole, L.J., Jr. Managerial strategies and behavior in networks: A model with evidence from U.S. public education. J. Public Adm. Res. Theory 2001, 11, 271-295. [CrossRef]

66. Chen, B. Assessing interorganizational networks for public service delivery. A process-perceived effectiveness framework. Public Perform. Manag. Rev. 2008, 31, 348-363. [CrossRef]

67. Burchielli, R.; Delaney, A.; Tate, J.; Coventry, K. The FairWear Campaign: An Ethical Network in the Australian Garment Industry. J. Bus. Ethics 2009, 90, 575-588. [CrossRef]

68. Silvestri, A.; Veltri, S.; Venturelli, A.; Petruzzelli, S. A research template to evaluate the degree of accountability of integrated reporting: A case study. Meditari Account. Res. 2017, 25, 675-704. [CrossRef]

69. Owen, D.; Swift, T.; Hunt, K. Questioning the role of stakeholder engagement in social and ethical accounting, auditing and reporting. Account. Forum 2001, 25, 264-282. [CrossRef]

70. Provan, K.G.; Milward, H.B. Do networks really work? A framework for evaluating public-sector organizational networks. Public Adm. Rev. 2001, 61, 414-423. [CrossRef]

71. Kapucu, N.; Garayev, V.; Wang, X. Sustaining Networks in Emergency Management. A Study of Counties in the United States. Public Perform. Manag. Rev. 2013, 37, 104-133. [CrossRef]

72. Bulińska-Stangrecka, H.; Bagieńska, A. Investigating the Links of Interpersonal Trust in Telecommunications Companies. Sustainability 2018, 10, 2555. [CrossRef]

73. O'Toole, L.J., Jr. Rational Choice and Public Management of Interorganizational Networks. In The State of Public Management; Kettl, D.F., Brinton Milward, H., Eds.; The Johns Hopkins University Press: Baltimore, MD, USA, 1996.

74. Simon, H. Behavioral model of rational choice In Models of Man, Social and Rational: Mathematical Essays on Rational Human Behavior in a Social Setting; Wiley: New York, NY, USA, 1957.

75. Kahneman, D.; Tversky, A. On the psychology of prediction. Psychol. Rev. 1973, 80, 237-251. [CrossRef]

76. McFadden, D. Rationality for economists. In Elicitation of Preferences; Springer: Dordrecht, The Netherland, 1999; pp. 73-110.

77. Behagel, J.H.; Arts, B. Democratic Governance and Political Rationalities in the Implementation of the Water Framework Directive in the Netherlands. Public Adm. 2014, 92, 291-306. [CrossRef]

(C) 2019 by the authors. Licensee MDPI, Basel, Switzerland. This article is an open access article distributed under the terms and conditions of the Creative Commons Attribution (CC BY) license (http://creativecommons.org/licenses/by/4.0/). 